\title{
Nordisk pendlingskarta 2012
}

Baserat på statistik från 2009

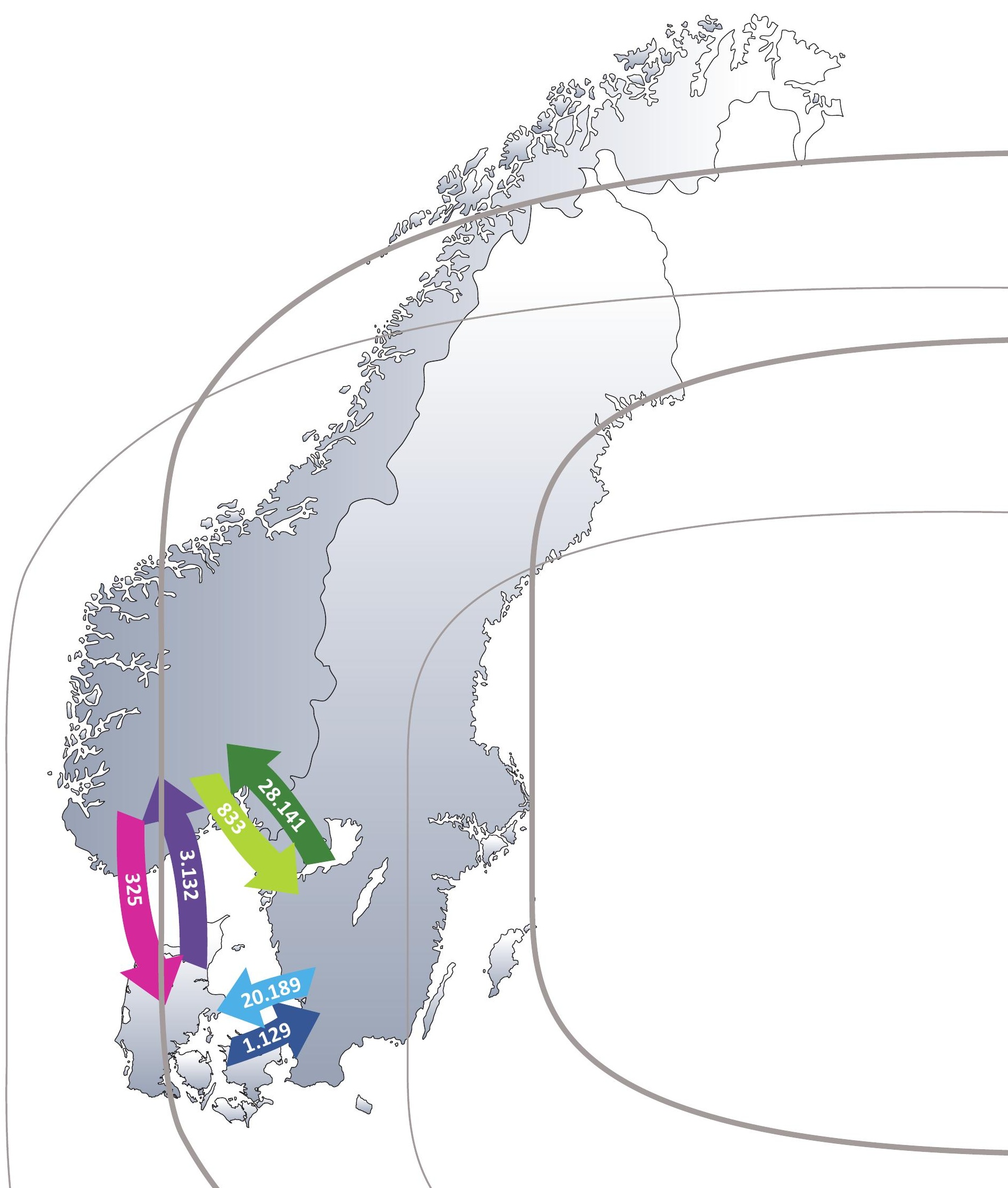



4 norden 



\section{Nordisk pendlingskarta 2012}

Baserat på statistik från 2009

TemaNord 2013:531 
Nordisk pendlingskarta 2012

Baserat på statistik från 2009

ISBN 978-92-893-2546-2

http://dx.doi.org/10.6027/TN2013-531

TemaNord 2013:531

(c) Nordiska ministerrådet 2013

Layout: Hanne Lebech

Omslagsfoto: B-Line

Tryck: Rosendahls-Schultz Grafisk

Upplaga: 516

Printed in Denmark

Denna rapport är utgiven med finansiellt stöd från Nordiska ministerrådet. Innehållet i rapporten avspeglar inte nödvändigtvis Nordiska ministerrådets synpunkter, åsikter eller rekommendationer.

\section{www.norden.org/sv/publikationer}

\section{Det nordiska samarbetet}

Det nordiska samarbetet är ett av världens mest omfattande regionala samarbeten. Det omfattar Danmark, Finland, Island, Norge och Sverige samt Färöarna, Grönland och Åland.

Det nordiska samarbetet är politiskt, ekonomiskt och kulturellt förankrat och är en viktig partner i europeiskt och internationellt samarbete. Den nordiska gemenskapen arbetar för ett starkt Norden i ett starkt Europa.

Det nordiska samarbetet ska stärka nordiska och regionala intressen och värderingar i en global omvärld. Gemensamma värderingar länderna emellan bidrar till att stärka Nordens ställning som en av världens mest innovativa och konkurrenskraftiga regioner.

\section{Nordiska ministerrådet}

Ved Stranden 18

DK-1061 København K

Telefon (+45) 33960200

www.norden.org 


\section{Innehåll}

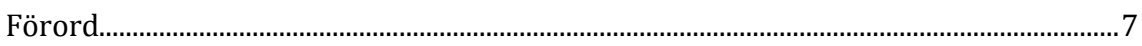

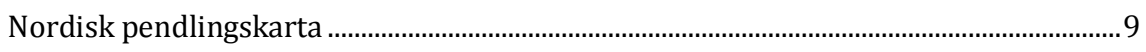

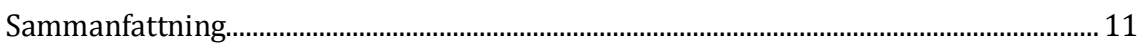

1. De gränsöverskridande arbetsströmmarnas storlek och utveckling......................... 13

1.1 Flest arbetspendlare från Sverige.................................................................... 13

1.2 Arbetspendlingen har mer än fördubblats......................................................... 14

2. Pendlarnas ålder, kön, utbildning m.m..................................................................... 17

3. Gränspendlingen efter bostadsland och näringsgren i arbetslandet........................ 23

3.1 Näringsgrenar med störst pendling efter bostadsland................................... 25

4. Gränspendlingens betydelse för den lokala arbetskrafts-försörjningen.................. 27

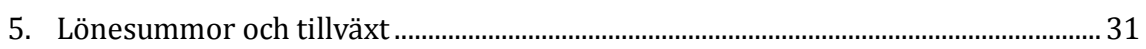

5.1 Svenska inkomsttagare slår av på takten ........................................................... 31

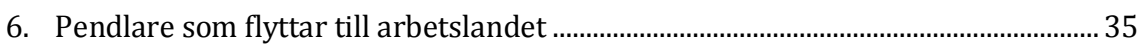

6.1 Många gränspendlande unga svenskar flyttar till Norge efter ett år........... 35

6.2 Normänn och danskar som flyttar till Sverige har inte pendlat

innan .................................................................................................................... 36

6.3 De fătaliga norska och danska gränspendlare som trots allt flyttar till jobbet i Sverige efter ett år är ofta födda i Sverige....................................... 37

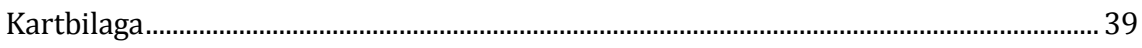

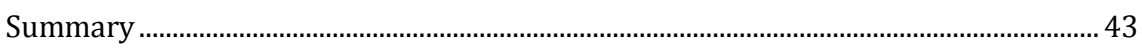

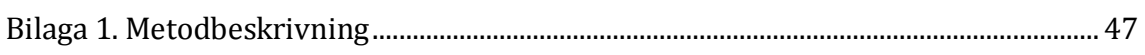

Bilaga 2. Största inpendlingsbransch för kommuner som tar emot mer än 50

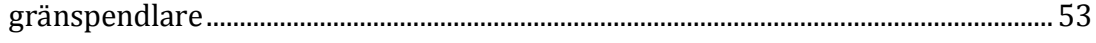

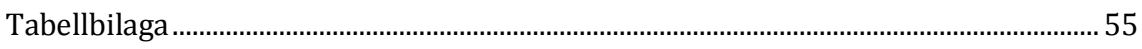





\section{Förord}

En av de viktigaste målsättningarna idet nordiska samarbetet är att främja den fria rörligheten I Norden för både privatpersoner och företag genom att bland annat aktivt verka for att identifiera och bryta ned gränshinder. Ett framgångsrikt granshindersarbete okar möjligheterna for medborgare som lever i en nordisk gransregion till att få tillgång till arbete som passar deras drömmar och förutsättningar.

Denna möjlighet ökar då de får tillgång till hela Nordens arbetsmarknad. Nordisk pendlingsstatistik visar att 70000 nordbor under 2009 utnyttjat den nordiska arbetsmarknaden. Detta ar en okning med 100 procent sedan 2001. Den samlade lönesumman for de nordiska granspendlare uppgick till 25 miljarder SEK varav 22 miljarder av summan tjänades av svenskar i Danmark och Norge.

Nordiska ministerrådets rapport Nordisk pendlingskarta bidrar med manga intressanta upplysningar om utvecklingen av pendlingen over gränserna i Norden.

Köpenhamn februari 2013

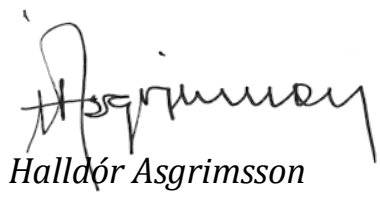

Generalsekretare

Nordiska ministerrådet 



\section{Nordisk pendlingskarta}

Nordisk pendlingskarta publiceras nu för sjätte gången. Statistikunderlagen som ligger till grund för rapporten är producerade i nära samarbete mellan statistikbyråerna i Danmark, Norge och Sverige. Statistik som avser Finland ingår i de fyra första årgångarna av rapporten. De tidigare sammanställningarna av pendlingsförhållandena i Norden baserades på situationen åren 2001, 2004, 2005, 2006 respektive 2008. Statistiken i denna rapport avser år 2009.

Syftet med rapporten är att beskriva den gränsöverskridande arbetsmarknaden för Danmark, Norge och Sverige. Samarbetet mellan statistikmyndigheterna sker bland annat genom ett utbyte av data, vilket har föregåtts av en särskild prövning i respektive land. Genom att bearbetningarna har gjorts på totalräknade register är det möjligt att redovisa statistik på nationell, regional och kommunal nivå, samt att beskriva rörligheten inom de berörda gränsregionerna.

Arbetet med metoder, beräkningar och redovisningar har utförts av:

- Pernille Stender vid Danmarks Statistik.

- Inge Aukrust, vid Statistisk Sentralbyrå i Norge.

- Sara Ekmark, Carl-Gunnar Hanaeus, Frida Wahlström, Linus Johansson, Oskar Nilsson och Mariette Thell, vid Statistiska centralbyrån i Sverige.

Statistiska Centralbyrån har fungerat som koordinator för projektet. Nordiska Ministerrådet svarar för finansiering och publicering av rapporten. 



\section{Sammanfattning}

Den kraftiga expansionen av svensk gränspendling till Danmark och Norge saktade in under 2009. Till Danmark minskade den med 600 personer och till Norge ökade den "bara" med 2000 personer, vilket innebar en total förändring på knappt 3 procent jämfört med 2008. Årsökningarna 2006-2008 var nära 20 procent eller ungefär 7000 personer per år.

Den danska gränspendlingen till Norge och Sverige låg kvar på samma nivå som under 2008, medan den norska pendlingen till Danmark och Sverige minskade med 20 procent.

Gränspendling har sedan 2001 ökat från 24800 till 53700 personer, vilket är en uppgång med 116 procent.

Under åren 2004-2006 ingick också pendlingsströmmarna till och från Finland i statistiken, vilket innebar att ytterligare 6000 gränspendlare då kunde räknas in. Sannolikt gränspendlade närmare 70000 nordbor under 2009.

\section{Skillnader mellan män och kvinnor i gränspendlingen}

Andelen gränspendlande kvinnor ökade med en procentenhet till 36 procent under 2009. Det återstår en bit till fördelningen 40/60 som brukar anges som jämställdhetsmål. Två pendlingsströmmar kan sägas vara jämställda, den på drygt 20000 pendlare från Sverige till Danmark och den mindre på 3100 från Danmark till Norge. I båda fallen är andelen kvinnor runt 40 procent.

\section{Många gränspendlar till sitt födelseland}

År 2009 var nästan 40 procent av de danska gränspendlarna till Norge och Sverige födda i inpendlingslandet. Bland danska kvinnor som pendlade till Norge var hela 71 procent födda i Norge. Av de svenska gränspendlarna till Danmark var 30 procent av kvinnorna och 40 procent av männen födda i Danmark. Därmed fanns det något fler danskfödda än svenskfödda män bland dem som pendlade från Sverige till Danmark.

\section{Gränspendlingen begränsar sig till ett fåtal branscher}

EU:s näringsgrensindelning NACE Rev.2 omfattar 21 avdelningar/branscher på enbokstavsnivå. Drygt tre fjärdedelar av gränspendlarna jobbade i sju av dessa branscher. 17 procent av samtliga pendlare jobbade inom branschen Uthyrning m.m, där bemanningsföretagen har 
tagit allt större andelar. Därefter kom verksamheten Handel; reparation av motorfordon och motorcyklar, som stod för ungefär 13 procent. Andra relativt stora näringsgrenar var Byggverksamhet, Transport och magasinering, Tillverkning samt Vård och omsorg. Gränspendlingen från Norge och Danmark gick främst till jobb inom Handeln, medan det för svensk del var Bemanningsbranschen som var störst.

\section{Det fanns branscher där företagen för sin arbetskraftsförsörjning var starkt beroende av inpendling}

Att det finns kompetens och arbetskraft som matchar företagens och de offentliga organisationernas behov är en förutsättning för en regions konkurrenskraft och tillväxt. För att klara arbetskraftsförsörjningen är många regioner i behov av en betydande inpendling.

I tretton norska och en dansk kommun utgjorde gränspendlarna mer är 15 procent av de förvärvsarbetande inom en specifik bransch. I danska Tårnby gällde det branschen Transport och magasinering. I Hemsedal, Trysil och Nol i Norge, var beroendet av gränspendlare inom Hotell- och restaurangverksamhet stort. I fem av de fjorton kommunerna var det bemanningsföretagen som i betydande omfattning anställde personer från grannlandet.

\section{5 miljarder SEK i löneinkomster}

År 2009 var det totala antalet löneinkomsttagare som arbetade i grannlandet nästan 99 000. Drygt hälften var arbetspendlare med huvudjobb i grannlandet. Den samlade lönesumman uppgick till 25 miljarder SEK, vilket var en ökning med 200 procent i löpande priser jämfört med 2001. Inflationsjusterat var ökningen ca 166 procent. Drygt 22 miljarder tjänades av svenskar i Danmark och Norge.

\section{Fler svenska ungdomar flyttar till jobben i Norge}

Under 1960- och 1970-talet emigrerade man i regel till det land där man jobbade. Under 2000-talet har man i högre utsträckning valt att bo kvar och pendla till grannlandet. 12 procent av norrmännen som gränspendlade till Sverige 2009 flyttade dit 2010. För dansk del var det 6 procent som flyttade till Sverige. 6 procent av svenskarna flyttade till Danmark och och 8 procent flyttade till Norge. Nya siffror visar att 12 procent av de svenska gränspendlarna 2010 flyttade till Norge 2011. Det är en dubblerad flyttningsandel jämfört med 2008. Det är ungdomar i åldrarna 16-24 år som flyttar.

Statistik som beskriver gränspendlingens koppling till flyttningar mellan Danmark och Norge produceras för närvarande inte. 


\section{De gränsöverskridande arbetsströmmarnas storlek och utveckling}

\subsection{Flest arbetspendlare ${ }^{1}$ från Sverige}

Sedan mätningarnas början, år 2001, har arbetspendlingen eller gränspendlingen, som den också benämns, inom Norden haft ungefär samma struktur. Dock avtog den stora expansionen av arbetspendling från Sverige under 2009. Mellan 2007 och 2008 ökade dentill Norge med nästan 6000 personer och till Danmark, där inbromsningen började ett år tidigare, med ca 1 200. För 2009 ökade den med knappt 2000 individer till Norge och till Danmark minskade den med drygt 600. I bilaga 1 finns en beskrivning av metoden att mäta gränspendling.

År 2009 gränspendlade 28100 respektive 20200 personer från Sverige till Norge respektive Danmark. Den klart minsta strömmen gick från Norge till Danmark med endast 320 arbetspendlare. Totalt arbetspendlade 53700 personer till ett annat land inom Skandinavien år 2009, 48300 av dem var bosatta i Sverige.

${ }^{1}$ Med begreppet arbetspendlare över riksgräns avses personer som har haft ett lönearbete under november månad i arbetslandet. Dessutom får inte årsinkomsten i hemlandet överstiga den i arbetslandet. Antalet arbetspendlare är en delmängd av antalet löneinkomsttagare. 
Diagram 1. Antal arbetspendlare 2009 efter pendlingsriktning

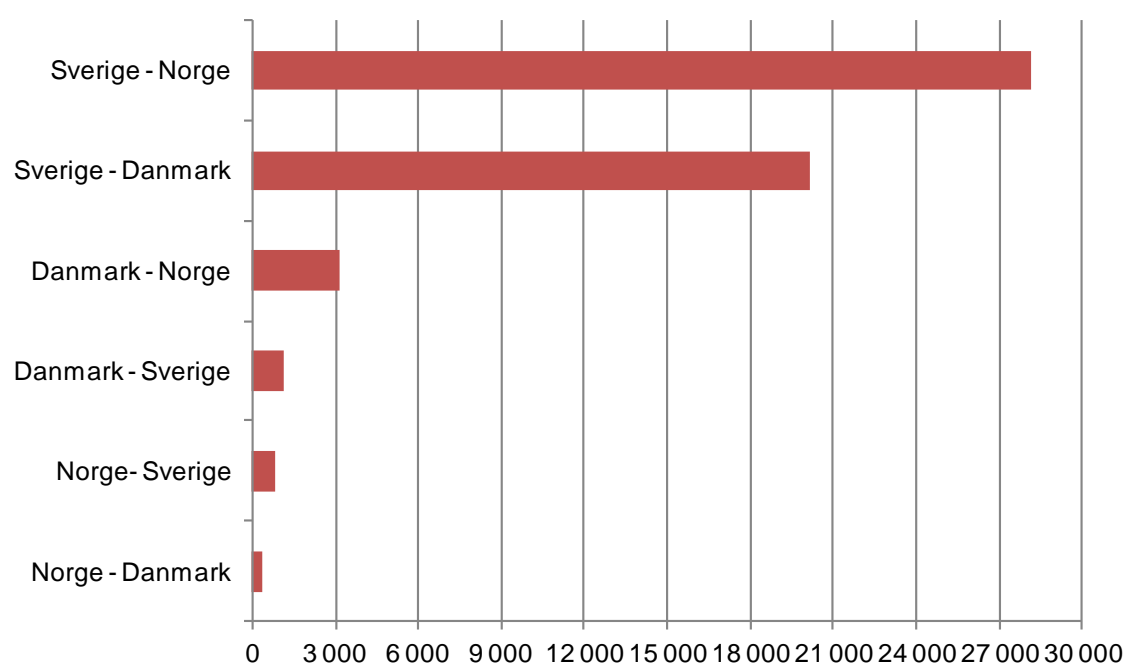

\subsection{Arbetspendlingen har mer än fördubblats}

Sedan den första mätningen av arbetspendlingen mellan Danmark, Norge och Sverige som genomfördes år 2001, ${ }^{2}$ har den totala pendlingen mellan länderna ökat med cirka 116 procent. Från 2006 till 2009 ökade antalet pendlare med 45 procent.

På längre sikt, mellan 2001 och 2009, har pendlingen från Sverige till Danmark svarat för den klart högsta procentuella ökningen med 336 procent. 2009 är dock första året sedan 2001 då antal pendlare från Sverige till Danmark minskat något, se diagram 2.

På lite kortare sikt mellan 2006 och 2009 har pendlingen från Sverige till Norge ökat mest, med 77 procent. Även arbetsspendlingen från Danmark till Norge har i viss mån ökat. I detta fall med 23 procent mellan åren 2006 och 2009. Övriga pendlingsströmmar visar en negativ utveckling på både kort och lång sikt, se diagram 3.

2 Sedan 1997 har beräkningar gjorts för Öresundregionen, men det första utbytet för hela Sverige och Danmark gjordes med uppgifter avseende 2001. 
Diagram 2. Utveckling arbetspendling mellan Sverige och Norge samt mellan Sverige och Danmark, 2001-2009

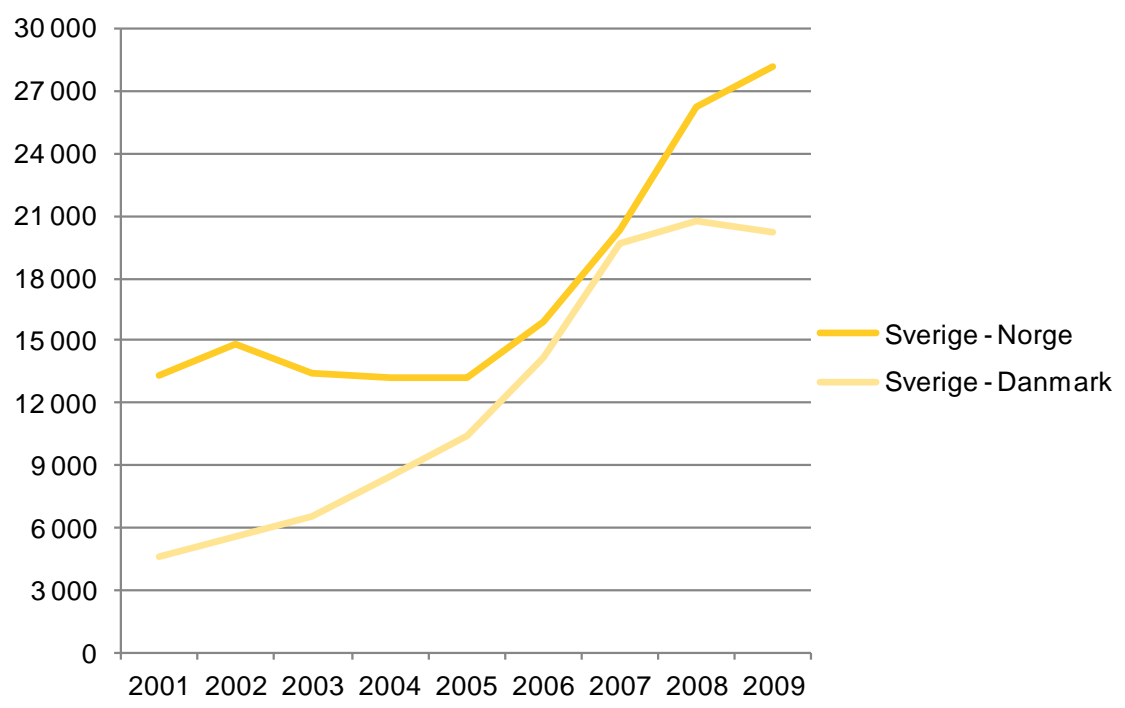

Utvecklingen för den historiskt sett största pendlingströmmen, den från Sverige till Norge, var under perioden 2001-2005 relativt begränsad. Från år 2006 och framåt har dock bilden förändrats. Mätningarna visar att antalet gränspendlare ökade med 20 procent under år 2006 och med nästan 30 procent under åren 2007 och 2008. Även under 2009 ökade antal pendlare från Sverige till Norge, men bara med 7 procent.

\section{Diagram 3 Utveckling övriga pendlingsströmmar, 2001-2009*}

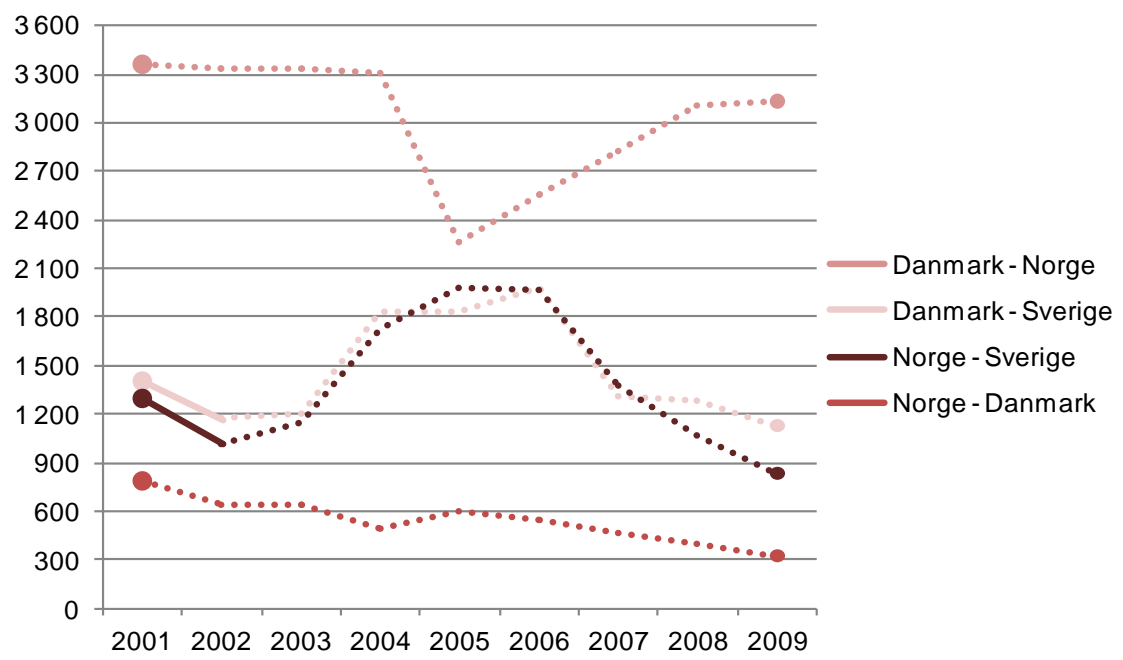

*Prickad linje visar att mätvärden saknas. Mätdata finns bara för åren 2001, 2004-2006 och 2008-2009. 
Antalet personer som pendlat från Norge till Danmark har, sett över hela tidsperioden, minskat med cirka 60 procent från knappt 800 personer till drygt 320 personer. Det är den enda pendlingsströmmen som visar en klart nedåtgående trend under hela tidsperioden. Övriga strömmar, bortsett från pendlare med Sverige som bostadsland, visar en mer otydlig bild där gränspendlingen ibland ökar och ibland minskar.

Norge är det land som har störst antal inpendlare samtidigt som nivån för arbetspendlingen ifrån landet ligger lägst. I likhet med Norge var det betydligt fler personer som pendlade till Danmark än som pendlade ut från landet.

Det klart största utpendlingslandet har under hela tidsperioden varit Sverige som mellan 2006 och 2009 ökade sin utpendling med nästan 18000 personer till totalt 48300 arbetspendlare (se tabell 1). Norge har varit det land dit flest svenskar arbetspendlar, Danmark närmade sig avsevärt under tidsperioden 2001 och 2007. Mellan åren 2007 och 2009 ökade dock pendlingen till Norge betydligt mer än den till Danmark.

Tabell 1. Antal arbetspendlare (15 år eller äldre) efter pendlingsriktning åren 2001, 2006 och 2009 samt procentuell förändring mellan 2001 och 2009 respektive 2006 och 2009

\begin{tabular}{|c|c|c|c|c|c|c|}
\hline \multirow[t]{2}{*}{ Bostadsland } & \multirow[t]{2}{*}{ Arbetsland } & \multicolumn{3}{|c|}{ Antal arbetspendlare } & \multicolumn{2}{|c|}{ Procentuell utveckling } \\
\hline & & 2001 & 2006 & 2009 & 2001-2009 & 2006-2009 \\
\hline Totalt & & 24849 & 37182 & 53749 & 116,3 & 44,6 \\
\hline \multirow[t]{3}{*}{ Danmark } & Norge & 3369 & 2551 & 3132 & $-7,0$ & 22,8 \\
\hline & Sverige & 1410 & 1980 & 1129 & $-19,9$ & $-43,0$ \\
\hline & Summa & 4779 & 4531 & 4261 & $-10,8$ & $-6,0$ \\
\hline \multirow[t]{3}{*}{ Norge } & Danmark & 798 & 547 & 325 & $-59,3$ & $-40,6$ \\
\hline & Sverige & 1300 & 1961 & 833 & $-35,9$ & $-57,5$ \\
\hline & Summa & 2098 & 2508 & 1158 & $-44,8$ & $-53,8$ \\
\hline \multirow[t]{3}{*}{ Sverige } & Danmark & 4636 & 14224 & 20189 & 335,5 & 41,9 \\
\hline & Norge & 13336 & 15919 & 28141 & 111,0 & 76,8 \\
\hline & Summa & 17972 & 30143 & 48330 & 168,9 & 60,3 \\
\hline
\end{tabular}




\section{Pendlarnas ålder, kön, utbildning m.m.}

Den nordiska gränspendlingen mellan Danmark, Norge och Sverige domineras av män. Andelen kvinnor ökade under 2009 med en procentenhet till 36 procent, men det är fortfarande skillnader mellan kvinnor och män. Danmark var det land med högst andel kvinnor, 38 procent. Andelarna från Sverige och Norge var 36 procent respektive 35 procent, se diagram 4 .

Diagram 4 Antal gränspendlare efter bostadsland och kön 2009

$$
\text { -Män } \square \text { Kvinnor }
$$

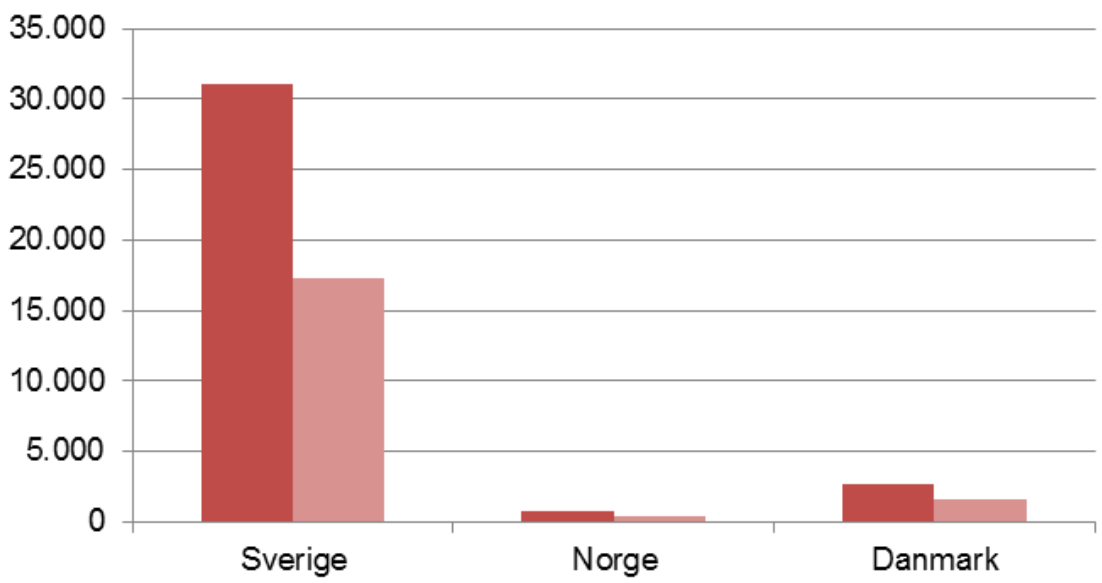

Bakom siffrorna döljer sig en del olikheter i de enkilda pendlingsvägarna från land till land. De norska kvinnorna har jämfört med 2008 minskat sin gränspendling till Danmark med 40 procent, vilket innebär att deras andel jämfört med männen är 29 procent medan deras andel till Sverige ligger kvar på 37 procent. De är inte så stor skillnad i antal mellan svenska kvinnor och män som pendlar till Danmark, kvinnornas andel är 41 procent, medan andelen till Norge är i stort sett oförändrad på 32 procent. Jämställt är det delvis också för de danska kvinnorna med andelen 40 procent av danska pendlare till Norge medan andelen till Sverige är oförändrat 32 procent jämfört med 2008. 


\subsubsection{Männen var i genomsnitt äldre än kvinnorna}

Den genomsnittliga åldern för samtliga pendlare var 35 år. Kvinnorna hade en klart lägre genomsnittsålder, 32 år jämfört med männens 37 år.

Den låga medelåldern hos kvinnorna bekräftas när vi delar upp gränspendlarna i olika åldersgrupper enligt diagram 5. Man ser tydligt att kvinnorna från alla tre länderna i åldrarna mellan 15 och 24 år är många, till och med fler än männen i samma åldrar. Unga kvinnor från Danmark utgjorde 45 procent av alla danska kvinnliga pendlare. Motsvarande siffra för Sverige och Norge var 35 respektive 31 procent.

I de efterkommande åldersgrupperna har det svängt om totalt, drygt 70 procent av pendlarna var män. Majoriteten av männen var mellan 25 och 54 år. Störst andel fanns bland svenska gränspendlare där de utgjorde 71 procent av alla manliga pendlare. Motsvarande andelar för Norge var 68 procent och Danmark 67 procent. Nästan hälften av samtliga gränspendlare var män mellan 25 och 54 år.

I den äldsta gruppen, 55 år och uppåt, var andelen män totalt 70 procent. Störst andel äldre män fanns bland pendlare från Norge och Danmark med 20 procent, medan 10 procent av svenskarna tillhörde denna grupp.

Diagram 5. Gränspendlare fördelat efter ålder, kön och bostadsland 2009. Andelar i procent

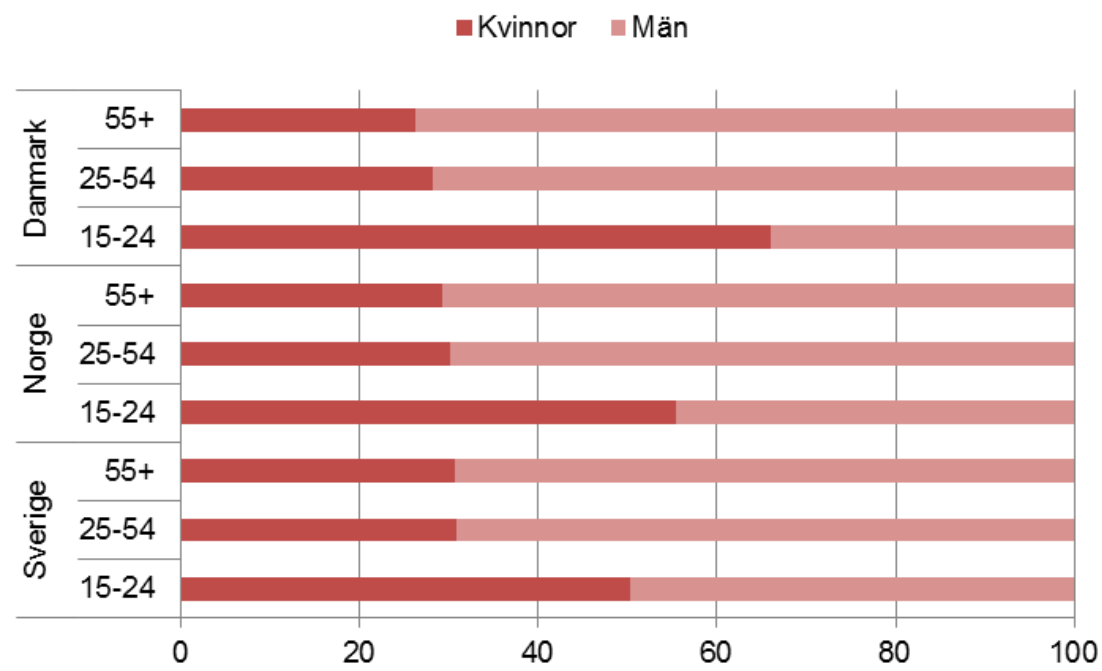




\subsection{2 Är integrationseffekten större eller mindre om man pendlar till sitt födelseland?}

Bland gränspendlarna som utgick från Sverige var 37 procent födda i annat land än Sverige. Jämfört med den nationella arbetsmarknaden i Sverige där ca 17 procent var födda i annat land. Skillnaden innebar att det fanns närmare 13000 fler utlandsfödda bland gränspendlarna år 2009, än om fördelningen skulle varit den samma som på den nationella arbetsmarknaden. Det visar sig att 12000 av dem var födda i det land dit de pendlade. Av de svenska gränspendlarna till Danmark var 31 procent av kvinnorna och 40 procent av männen födda i Danmark. För männens del innebar det att det att antalet danskfödda var fler än antalet svenskfödda bland pendlarna som jobbade i Danmark. Nästan 40 procent av de danska gränspendlarna till Norge eller Sverige var födda där. Bland danska kvinnorna som pendlar till Norge var hela 71 procent födda $\mathrm{i}$ Norge. Se även diagram 6.

Det kan finnas många anledningar till att jobba i sitt födelseland samtidigt som man bor i ett annat nordiskt land. När Öresundsbron färdigställdes var det många danskar som flyttade till den svenska sidan av sundet och behöll jobben i Köpenhamnsregionen. Det var billigare att bo i Sverige och restiden till jobbet påverkades inte så mycket, den kanske till och med minskade. Vi kan i dessa fall snarare tala om bostadspendling än arbetspendling. Men integrationseffekten var kanske större, de flyttade till grannlandet, med allt vad det innebar av nya nätverk och behöll samtidigt sina band till födelselandet genom att ha sin arbetsplats och sina kollegor där. 
Diagram 6. Gränspendlare efter bostadsland och födelseland 2009. Andelar i procent
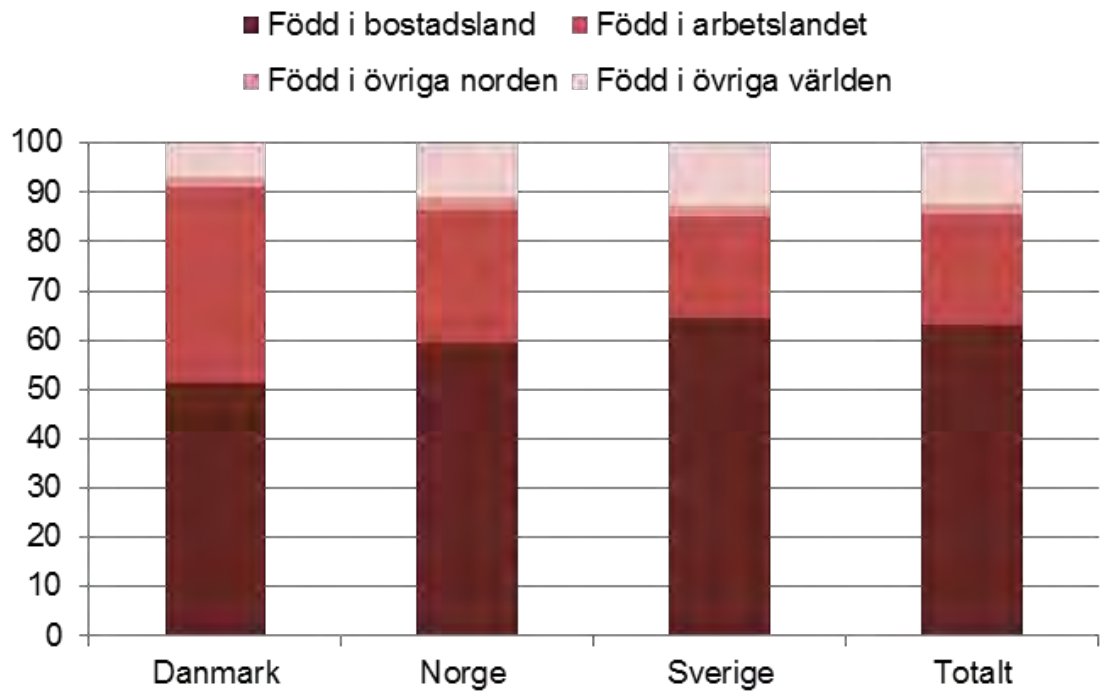

*Övriga norden innefattar förutom de jämförda länderna även Finland och Island.

\subsubsection{Utbildningsnivå}

Totalt hade 57 procent av de nordiska arbetspendlarna gymnasial utbildning och 30 procent hade eftergymnasial utbildning. Högst andel med eftergymnasial utbildning fanns bland arbetspendlarna bosatta i Danmark med 42 procent. I Norge var motsvarande andel 41 procent. Lägst andel hade de svenska pendlarna med 28 procent. Se diagram 7.

Diagram 7. Gränsendlare efter utbildningsnivå 2009. Andelar i procent

@ Okänd Eftergymnasial @ Gymnasial $\square$ Förgymnasial

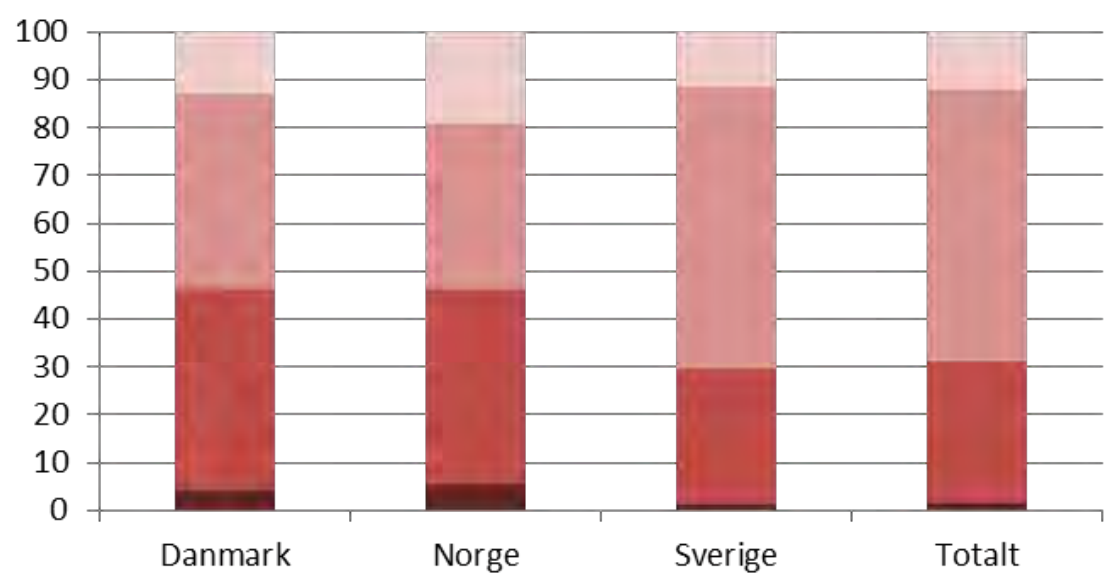




\subsubsection{Utbildningsinriktning}

För att utveckla beskrivningen av gränspendlarnas utbildning redovisas huvudinnehållet i de olika utbildningarna, det vill säga utbildningarnas inriktning. Liksom för utbildningsnivån följer redovisningen den internationella standarden för utbildningsklassificering, ISCED 97.

En fjärdedel av pendlarna hade genomgått de breda studieförberedande utbildningar som finns på förgymnasial och gymnasial nivå. Här skulle det vara av intresse att se hur många som gick vidare i utbildningstrappan och till vilka jobb och i vilket land de i så fall hamnade efter avslutade utbildningar. Man frågar sig om tiden och jobbet i grannlandet är en tidsbegränsad aktivitet innan man går vidare i sin jobbkarriär. De bakomliggande faktorer som t.ex. styr de svenska ungdomarnas ökade flyttningsbenägenhet skulle i det sammanhanget vara av intresse att studera.

En lika stor grupp hade utbildningar som lämpar sig för jobb inom teknik och tillverkning. Tre fjärdedelar av dem hade gymnasieutbildning och den återstående fjärdedelen hade eftergymnasial utbildning.

Dessutom fanns en betydande grupp på 14 procent med inriktning på Företagsekonomi, handel och administration, liksom gruppen som bl.a. bestod av läkare och sjuksköterskor inom Hälso- och sjukvård samt social omsorg och som uppgick till 13 procent. 



\section{Gränspendlingen efter bostadsland och näringsgren i arbetslandet}

Arbetspendlingen mellan Danmark, Norge och Sverige kan delas upp efter näringsgren genom att varje arbetsställe, som gränspendlarna jobbat på, har en näringsgrenskod, en bransch. I varje land klassificeras alla arbetsställen efter sin huvudsakliga verksamhet enligt den internationella näringsgrensklassificeringen NACE. ${ }^{3}$ Från och med 2009 års statistik används en ny gruppering, NACE rev. 2.0, som på ett bättre sätt redovisar näringslivets struktur, men som gör det svårare att göra jämförelser med tidigare utgivningar av rapporter i serien Nordisk pendligskarta. Se slutet av bilaga 2 . 
Tabell 2. Gränspendling efter näringsgren NACE rev.2.0. År 2009

\begin{tabular}{|c|c|c|}
\hline Näringsgren & Antal 2009 & Andel i \% 2009 \\
\hline Totalt & 53749 & 100 \\
\hline Uthyrning, fastighetsservice, resetjänster och andra stödtjänster & 8404 & 16,9 \\
\hline Handel; reparation av motorfordon och motorcyklar & 7202 & 13,3 \\
\hline Byggverksamhet & 5695 & 10,8 \\
\hline Transport och magasinering & 5810 & 10,4 \\
\hline Tillverkning & 4830 & 9,4 \\
\hline Vård och omsorg; sociala tjänster & 5422 & 8,9 \\
\hline Hotell och restaurang & 4635 & 8,1 \\
\hline Verksamhet inom juridik, ekonomi, vetenskap och teknik & 2442 & 4,9 \\
\hline Informations- och kommunikationsverksamhet & 1917 & 3,8 \\
\hline Offentlig förvaltning och försvar; obligatorisk socialförsäkring & 1563 & 2,8 \\
\hline Utbildning & 1285 & 2,2 \\
\hline Finans- och försäkringsverksamhet & 1118 & 2,2 \\
\hline Kultur, nöje och fritid & 1163 & 2,1 \\
\hline Utvinning av mineral & 681 & 1,5 \\
\hline Annan serviceverksamhet & 566 & 0,9 \\
\hline Fastighetsverksamhet & 347 & 0,6 \\
\hline Jordbruk, jakt och skogsbruk & 341 & 0,6 \\
\hline Vattenförsörjning; avloppsrening, avfallshantering och sanering & 130 & 0,2 \\
\hline Försörjning av el, gas, värme och kyla & 69 & 0,1 \\
\hline Verksamhet vid internationella organisationer, utländska ambassader o.d.* & 33 & 0,0 \\
\hline $\begin{array}{l}\text { Förvärvsarbetande i hushåll; hushållens produktion av diverse varor och } \\
\text { tjänster för eget bruk }\end{array}$ & 13 & 0,0 \\
\hline Okänd näringsgren & 83 & 0,3 \\
\hline
\end{tabular}

* Ambassadpersonal folkbokförs i arbetslandet.

Drygt tre fjärdedelar av pendlingen mellan Danmark, Norge och Sverige gjordes till jobb inom sju av de 21 branschavdelningarna. Den högsta andelen av pendlingen, ca 17 procent, avsåg arbeten inom Uthyrning, fastighetsservice, resetjänster och andra stödtjänster, därefter kom branschen Handel, som stod för drygt 13 procent. Stora brancher var även Transport och magasinering samt Byggverksamhet vars andelar var ca 11 respektive ca 10 procent. Se tabell 2. 


\subsection{Näringsgrenar med störst pendling efter bostadsland}

I tabellerna nedan redovisas de sex största näringsgrenarna för arbetspendlare från Danmark, Norge och Sverige.

\begin{tabular}{lrr} 
Tabell 3. Antalet gränspendlare från Danmark till övriga länder efter näringsgren. År 2009 \\
\hline Näringsgren & Antal & Andel i \% \\
\hline Handel; reparation av motorfordon och motorcyklar & 566 & 13,3 \\
Vård och omsorg; sociala tjänster & 433 & 10,2 \\
Uthyrning, fastighetsservice, resetjänster och andra stödtjänster & 369 & 8,7 \\
Utvinning av mineral & 333 & 7,8 \\
Verksamhet inom juridik, ekonomi, vetenskap och teknik & 332 & 7,8 \\
Transport och magasinering & 330 & 7,7 \\
\hline
\end{tabular}

Av de personer som var bosatta i Danmark och sysselsatta i Norge eller Sverige arbetade flest inom Handeln. Arbete inom Vård och omsorg var den näst största branschen. Branschstrukturen i övrigt är relativt jämn för danskarna jämfört med de övriga länderna. Utvinning av mineral, verksamhet inom Juridik m.m. och Transport och magasinering stod för 8 procent vardera.

Tabell 4. Antalet gränspendlare från Norge till övriga länder efter näringsgren. År 2009

\begin{tabular}{lrr}
\hline Näringsgren & Antal & Andel i \% \\
\hline Handel; reparation av motorfordon och motorcyklar & 297 & 25,6 \\
Transport och magasinering & 167 & 14,4 \\
Vård och omsorg; sociala tjänster & 109 & 9,4 \\
Utbildning & 93 & 8,0 \\
Tillverkning & 73 & 6,3 \\
Verksamhet inom juridik, ekonomi, vetenskap och teknik & 70 & 6,0 \\
\hline
\end{tabular}

Av de branscher som sysselsatte norrmän i Danmark eller Sverige var Handel den klart dominerande. En fjärdedel av alla gränspendlare bosatta i Norge fanns inom denna branch. Majoriteten av dessa arbetade i svenska gränskommuner. 
Tabell 5. Antalet gränspendlare från Sverige till övriga länder efter näringsgren. År 2009

\begin{tabular}{lrr}
\hline Näringsgren & Antal & Andel i \% \\
\hline Uthyrning, fastighetsservice, resetjänster och andra stödtjänster & 7977 & 16,5 \\
Handel; reparation av motorfordon och motorcyklar & 6339 & 13,1 \\
Byggverksamhet & 5360 & 11,1 \\
Transport och magasinering & 5313 & 11,0 \\
Vård och omsorg; sociala tjänster & 4880 & 10,1 \\
Tillverkning & 4472 & 9,3 \\
\hline
\end{tabular}

För svenska gränspendlare är Uthyring, fastighetsservice, resetjänster och andra stödtjänster den dominerande branschen. I den här gruppen ingår arbetsställen inom bemanningsbranchen som länge har varit en viktig bransch för pendlingen mellan Sverige och Norge. Näst vanligaste branch för svenskarna var Handel följt av Byggverksamhet samt Transport och magasinering. 


\section{Gränspendlingens betydelse för den lokala arbetskrafts- försörjningen}

I det föregående avsnittet redovisades vilka branscher som var vanligast bland gränspendlare från Danmark, Norge och Sverige, men det är inte bara ur bostadslandets perspektiv som denna kunskap är viktig. Inpendlingen har ibland stor betydelse för tillgången på arbetskraft inom olika branscher i näringslivet.

Att det finns kompetens och arbetskraft som matchar företagens och offentliga organisationers behov är en förutsättning för en regions konkurrenskraft och tillväxt. Åldersstrukturen i många länder, däribland de nordiska, innebär att många lämnar arbetsmarknaden samtidigt som många nya inträder. Parallellt pågår en strukturomvandling inom industri och tjänstenäringar som medfört en större efterfrågan på specialistkompetens inom många branscher. Dessa faktorer har inneburit att frågor kring matchning och kompetensförsörjning fått en framträdande roll i många regioner.

Det finns flera faktorer som påverkar matchningsmekanismen och kompetensförsörjningen på arbetsmarknaden. Utbildning, befolkningsutveckling och flyttningar är några, men för att klara arbetskraftsförsörjningen är många kommuner i behov av en betydande inpendling. ${ }^{4}$

Inpendling förser kommunens företag med arbetskraft och stärker därigenom kommunens konkurrenskraft. Ökad ekonomisk tillväxt inom en bransch kan även ge lokala spridningseffekter till andra branscher. Den lokala efterfrågan på arbetskraft kan därigenom öka och fler olika typer av arbeten kommer att efterfrågas.

I det här avsnittet försöker vi med en kartografisk presentation att beskriva gränspendlingens betydelse för näringslivet på kommunnivå. Vi har valt ut de kommuner och branscher där gränspendlingen var störst. Kar-

4 "Regionernas arbetskraftsförsörjning", Tillväxtanalys dnr 2009/278 
tan används också för att identifiera olika regionala mönster, där vissa typer av regioner särskilt påverkas av inpendlingen till en viss bransch.

Gränspendlingens inverkan på den enskilda branschen och kommunen sker i flera dimensioner och är en mycket komplex fråga. I avsnittets sista stycke försöker vi närma oss denna problematik. Det görs genom att jämföra antalet inpendlare med antalet övriga anställda (antalet sysselsatta som bor och arbetar i samma land) i de branscher som var vanligast för gränspendlingen i respektive kommun. Vi identifierar på det sättet "hotspots", där sambandet mellan näringsliv och gränspendling var särskilt starkt.

I det första steget gör vi en avgränsning av de kommuner som haft den största inpendlingen under 2009. Det gör vi genom att enbart ta med kommuner som hade fler än femtio inpendlare totalt från de två andra länderna som ingår i rapporten. I Norge handlade det om 68 kommuner, i Danmark 31 och i Sverige 6 kommuner.

I steg två väljs de branscher ut som hade det högsta antalet gränspendlare i de 105 kommunerna. Tabell 6 nedan är en sammanställning för de tre länderna.

\begin{tabular}{|c|c|c|c|}
\hline Näringsgren & $\begin{array}{r}\text { Antal kommuner } \\
\text { Danmark }\end{array}$ & $\begin{array}{r}\text { Antal kommuner } \\
\text { Norge }\end{array}$ & $\begin{array}{r}\text { Antal kommuner } \\
\text { Sverige }\end{array}$ \\
\hline $\begin{array}{l}\text { Handel; reparation av motorfordon och } \\
\text { motorcyklar }\end{array}$ & 12 & 6 & 2 \\
\hline Byggverksamhet & 1 & 18 & 0 \\
\hline $\begin{array}{l}\text { Uthyrning, fastighetsservice, resetjänster och } \\
\text { andra stödtjänster }\end{array}$ & 0 & 16 & 0 \\
\hline Tillverkning & 4 & 10 & 0 \\
\hline Vård och omsorg; sociala tjänster & 10 & 3 & 0 \\
\hline Transport och magasinering & 2 & 6 & 2 \\
\hline Hotell och restaurang & 0 & 8 & 0 \\
\hline Utvinning av mineral & 0 & 1 & 0 \\
\hline $\begin{array}{l}\text { Verksamhet inom juridik, ekonomi, veten- } \\
\text { skap och teknik }\end{array}$ & 1 & 0 & 1 \\
\hline Utbildning & 0 & 0 & 1 \\
\hline Finans- och försäkringsverksamhet & 1 & 0 & 0 \\
\hline
\end{tabular}


De branscher som var vanliga känns igen från tidigare avsnitt. I Danmark var Handel m.m. och Vård och omsorg de vanligaste arbetsbranscherna för gränspendlarna i ungefär två tredjedelar av de valda kommunerna. För Norge visar tabellen att Byggverksamhet och Uthyrning m.m. var de dominerande branscherna i knappt 50 procent av kommunerna. Inpendlingen till Sverige var den absolut lägsta bland de tre länderna. Det bekräftas av att det bara fanns 6 kommuner med fler än 50 inpendlare under 2009.

Kartan i bilaga 2 visar största näringsgren för inpendlarna i de 105 valda kommunerna. Vi tycker oss kunna identifiera några mönster eller samband mellan olika regiontyper och olika typer av inpendling.

Handel m.m. var den vanligaste arbetsbranschen för gränspendlare till många kommuner i de danska storstadsområdena Köpenhamn, Århus och Odense. Det fanns även fem kommuner i Osloområdet där arbete inom denna bransch var vanligast. I Sverige spelade inpendlingen till Handel m.m. en viktig roll i gränshandelskommunerna Malmö och Strömstad.

Inpendlingen har varit betydande till de flesta av kommunerna i norra Själland. Inflödet av arbetskraft till arbeten inom Vård och omsorg har varit särskilt viktig för ett kluster av kommuner kring Helsingör, i den norra delen av regionen.

Totalt gränspendlade ca 5100 personer till arbete inom byggbranschen 2009. För många kommuner i de sydöstra delarna av Norge har inpendlingen till denna bransch varit särskilt viktig. Från Norge utpendlade ingen till byggbranschen i Danmark eller Sverige.

Till flertalet av de norska kommunerna längs den södra delen av den norsk-svenska gränsen har inpendling varit stor. Kartan visar en sträng av kommuner, från Halden i söder till Aurskog-Hølands kommun i norr, där inpendlingen till arbeten inom tillverkningsindustrin var vanlig. Det totala antalet anställda inom denna bransch var relativt högt i flera av dessa kommuner. Sammantaget kan det vara en indikation på att den geografiska närheten till relativt billig arbetskraft från Sverige har haft betydelse för tillverkningsindustrin i detta område.

Inpendlingen till arbete inom hotell- och restaurangverksamhet var störst i kommuner där fjällturism har en framträdande roll, såsom Lillehammer, Trysil och Hemsedal. Säsongsarbete är vanligt förekommande inom denna bransch. "Mörkertalet" blir därigenom stort då säsonganställda till följd av små lönsummor (ackumulerade löneinkomster) ibland inte uppfyller kraven för att klassificeras som gränspendlare.

Uthyrning, fastighetsservice, resetjänster och andra stödtjänster är den vanligaste branschen bland inpendlare till Norge. Inom den branschen finns bemanningsföretagen som bedriver personaluthyrning till 
andra företag. Ofta talar man om personaluthyrningsföretag. I kartan kan man skönja två typer av kommuner där dessa spelat en särskild roll. Den ena gruppen utgörs av stora kommuner såsom Oslo, Stavanger, Bergen och Trondheim. Den andra gruppen är kustkommuner från Sandnäs i söder till Alta i norr. Tyvärr finns det ingen information om vilken bransch som dessa individer varit uthyrda till, men det finns anledning att tro att det i kustkommunerna handlar det mycket om arbeten inom den norska fiskeindustrin.

Slutligen har vi i tabell 7 identifierat "hotspots" där inpendlingen varit särskilt viktigt för kommunen och dess företag. Vi gör det genom att jämföra antalet sysselsatta enligt den nationella statistiken med antalet inpendlare från annat nordiskt land inom samma bransch. Det finns totalt 14 kommuner där gränspendlarna har en andel som är över 15 procent av samtliga sysselsatta inom en specifik bransch. Flertalet av dessa kommuner ligger i Norge. I samtliga fall där Uthyrning, fastighetsservice, resetjänster och andra stödtjänster anges som näringsgren handlar det om kustkommuner i Norge. Arbetskraftsförsörjningen som helhet och till bemanningsbranschen i synnerhet var till stor del beroende av inpendlingen från andra nordiska länder. Den enda icke norska kommunen är Tårnby, hemkommun för Nordens största flygplats Kastrup. Nästan hälften av den personal som där arbetar inom Transport och magasinering är inpendlare. Tabellen visar således några tydliga exempel på kommuner där integrationen av den nordiska arbetsmarknaden varit viktig och i vissa fall en förutsättning för kommunens och företagens verksamhet.

Tabell 7 Kommuner och branscher där beroendet av inpendlande arbetskraft var stort år 2009. Andelar i procent

\begin{tabular}{lllr}
\hline Land & Kommun & Näringsgren & $\begin{array}{r}\text { Andel sysselsatta som är } \\
\text { gränspendlare }\end{array}$ \\
\hline Norge & Nordreisa & Uthyrning mm, & 77,6 \\
Norge & Verdal & Uthyrning mm, & 40,1 \\
Danmark & Tårnby & Transport och magasinering & 32,5 \\
Norge & Hemsedal & Hotell och restaurang & 28,8 \\
Norge & Trysil & Hotell och restaurang & 26,4 \\
Norge & Haram & Uthyrning mm, & 24,5 \\
Norge & Hammerfest & Uthyrning mm, & 24,2 \\
Norge & Eidsberg & Tillverkning & 19,8 \\
Norge & Sør-Varanger & Byggverksamhet & 19,4 \\
Norge & Sandefjord & Uthyrning mm, & 17,9 \\
Norge & Hol & Hotell och restaurang & 17,3 \\
Norge & Eidskog & Tillverkning & 16,2 \\
Norge & Grue & Byggverksamhet & 15,4 \\
Norge & Marker & Tillverkning & 15,3 \\
\hline
\end{tabular}




\section{Lönesummor och tillväxt}

Med hjälp av de kontrolluppgifter som årligen samlas in från arbetsgivarna sammanställs statistik över lönesummor. De kan användas som indikator för att följa produktionsutveckling och ekonomisk tillväxt på regional nivå och är ibland en viktig komponent i nationalräkenskapsberäkningar av Bruttonationalprodukt, BNP, för ett helt land.

En positiv lönesummeutveckling för dagbefolkningen, det vill säga för alla som jobbar i en specifik kommun oavsett om de bor där eller ej, innebär i de flesta fall att fler jobb har tillkommit i regionen.

Lönesummeberäkningarna i denna rapport omfattar samtliga personer som har haft en löneinkomst i ett grannland. Lönesummorna har räknats om till svensk valuta efter mittkurserna för respektive år. ${ }^{5}$

År 2009 arbetade totalt 99000 löneinkomsttagare (se bilaga 1 för definition av löneinkomsttagare) i ett nordiskt grannland. Det har tidigare i rapporten framgått att 53700 av dem hade sitt huvudsakliga jobb i grannlandet och att de därmed klassificerades som arbetspendlare.

\subsection{Svenska inkomsttagare slår av på takten}

Sedan 2001 har antalet svenskar med löneinkomster i annat nordiskt land mer än fördubblats. De senaste åren, fram till 2008, syns en tydlig ökning av svenskar med inkomster i Danmark och Norge. Den tydliga uppåtgående trenden av svenskar med inkomster i Norge verkar ha avtagit något 2009. Jämfört med 2008 har antalet svenskar med inkomster i Danmark till och med minskat med drygt 600 personer, se tablå 9 .

Till skillnad mot den, om än svaga, uppgången för antalet svenska inkomsttagare har antalet inkomsttagare från de andra länder visat en svagt nedåtgående trend, se diagram 8. Sedan 2001 har antalet norska inkomsttagare i Danmark eller Sverige minskat med 26 procent, se tablå 10 . Antalet danska inkomsttagare i Norge eller Sverige har minskat med 19 procent.

${ }^{5}$ I och med omräkningen till svensk valuta kan förändringar i relationerna mellan ländernas valutor påverka statistiken. 
Diagram 8 Antal löneinkomsttagare efter bostads- och arbetsland åren 2001 och $2009 *$

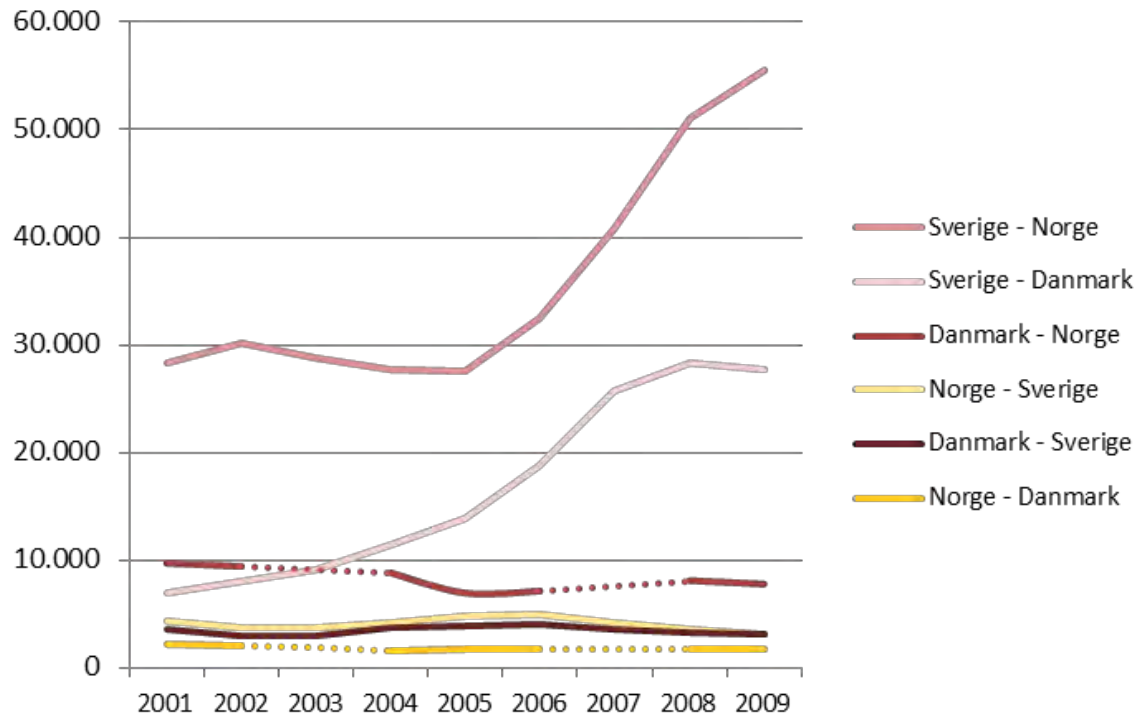

*Prickad linje visar att mätvärden saknas. Mätdata finns bara för åren 2001, 2004-2006 och 2008-2009.

Den totala lönesumman, intjänad i grannlandet och i löpande priser, har ökat med nästan 200 procent jämfört med 2001. (Med hänsyn tagen till prisutvecklingen var ökningen ca 166 procent.) Svenska inkomsttagare stod för den största delen av ökningen. Som framgår av tablå 9 har lönesumman för svenskar som arbetat i Danmark ökat med anmärkningsvärda 501 procent sedan 2001. Även i Norge har svenska inkomstagare haft en god lönesummeutveckling, 181 procent. Lönesummeökningen beror dels på generella löneökningar, men framförallt på ökningen av antalet inkomsttagare. Lönesumman för norrmän med inkomster i grannländerna har minskat med 25 procent sedan 2001, motsvarande för danskar var en ökning med 7 procent. Mellan år 2008 och 2009 ökade lönesumman för svenska inkomsttagare med 18 procent, se tabell 8. 
Tabell 8. Antalet inkomsttagare efter bostadsland och arbetsland åren 2001, 2008 och 2009 samt den procentuella lönesummeutvecklingen i SEK mellan 2001 och 2009 samt mellan 2008 och 2009 i löpande priser

\begin{tabular}{|c|c|c|c|c|c|c|}
\hline Bostadsland & Arbetsland & $\begin{array}{r}\text { Antal } \\
2001\end{array}$ & $\begin{array}{r}\text { Antal } \\
2008\end{array}$ & $\begin{array}{r}\text { Antal } \\
2009\end{array}$ & $\begin{array}{r}\text { Procentuell löne- } \\
\text { summeutveckling i SEK } \\
2001-2009\end{array}$ & 2008-2009 \\
\hline Totalt & & 55254 & 96199 & 98948 & 198,2 & 12,0 \\
\hline \multirow[t]{3}{*}{ Danmark } & Norge & 9735 & 8120 & 7797 & $-3,5$ & $-30,4$ \\
\hline & Sverige & 3663 & 3331 & 3093 & 32,0 & 3,0 \\
\hline & Summa & 13398 & 11451 & 10890 & 7,2 & $-20,8$ \\
\hline \multirow[t]{3}{*}{ Norge } & Danmark & 2275 & 1821 & 1702 & $-43,3$ & $-39,2$ \\
\hline & Sverige & 4291 & 3542 & 3172 & $-5,2$ & $-14,7$ \\
\hline & Summa & 6566 & 5363 & 4874 & $-25,1$ & $-26,5$ \\
\hline \multirow[t]{3}{*}{ Sverige } & Danmark & 7005 & 28284 & 27668 & 501,1 & 23,3 \\
\hline & Norge & 28285 & 51101 & 55516 & 180,9 & 12,4 \\
\hline & Summa & 35290 & 79385 & 83184 & 281,8 & 17,5 \\
\hline
\end{tabular}

Under 2009 hade personer bosatta i Norge, Danmark och Sverige sammanlagda löneinkomster på nära 25 miljarder SEK som de tjänat in i något av grannländerna. Som tidigare nämnts stod svenska inkomsttagare för den största delen, 90 procent av lönesumman, vilket motsvarade drygt 22 miljarder SEK (se diagram 9).

Diagram 9 Andelen av inkomsttagarnas lönesummor efter pendlingsriktning (bostadsland-arbetsland)

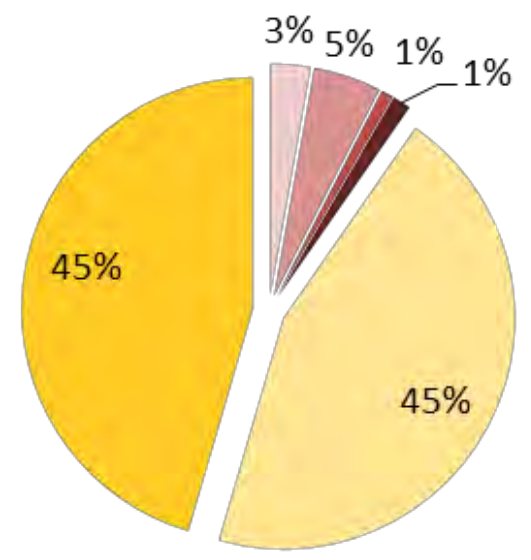

Danmark - Sverige

Danmark - Norge

Norge - Danmark

Norge - Sverige

Sverige - Danmark

Sverige - Norge 



\section{Pendlare som flyttar till arbetslandet}

Under 1960- och 1970-talet flyttade finländare och danskar till jobben i Sverige. Under 2000-talet första decennium valde framförallt många svenskar att bo kvar i hemlandet och istället pendla till jobb i grannlandet. Flera faktorer kan ha underlättat pendling mellan länderna under 2000-talet, bättre kommunikationer, arbetsmarknader där anknytningen till jobbet ser annorlunda ut, bl.a. beroende på olika anställningsformer och ökande inslag av tjänsteverksamhet istället för industrijobb. Det kan också ha med funktionerna och priserna på bostadsmarknanden att göra. Det kan finnas anledning att närmare studera hur flyttningar och gränspendling hänger samman, att nyansera bilden av arbetskraftsflödena mellan de nordiska länderna. I Sverige pendlar en tredjedel av de förvärvsarbetande över en kommungräns inom Sverige. Är gränspendlingen en naturlig utveckling i detta perspektiv? Innebär möjligheten att pendla mellan länderna att den nordiska integrationen har ökat eller skulle den varit större om man inte haft möjlighet att pendla utan istället flyttat till grannlandet för att finna jobb? Här presenteras några statistiska uppgifter som kan ses som inspel när man funderar över detta.

\subsection{Många gränspendlande unga svenskar flyttar till Norge efter ett år}

Norge och Danmark har varit de två populäraste utflyttningsländerna för de svenska emigranterna, och ökningen av antalet emiganter till dessa båda länder är tydlig, 2011 valde ca 10000 personer att flytta till Norge och 5000 till Danmark, vilket är dubblering sedan år 2000.

Av de svenska gränspendlarna flyttar sex av hundra till pendlingsländerna Danmark och Norge det efterföljande året. I mätningen år 2009 noterades dock en ökande andel, 8 procent, som flyttade till Norge under 2010. Nyare statistik visar att 12 procent av svenskarna som gränspendlade till Norge under 2010 flyttade till Norge året efter. Det är en dubblering jämfört med andelen flyttare 2009. Det är de mer flyttningsbenägna ungdomarna i åldrarna 15-24 år som står för denna ökning och det 
hänger också samman med att den totala andelen ungdomar bland gränspendlarna till Norge har ökat. Se diagram 10.

Av de gränspendlare som flyttade från Sverige till det tidigare inpendlingslandet Danmark (6 procent) var sju av tio återflyttande danskar. Av de som flyttade till Norge var till 60-80 procent, beroende på flyttningsår, svenskfödda som bosatte sig i arbetslandet.

Diagram 10 Gränspendlare från Sverige till Danmark respektive Norge som flyttar till inpendlingslandet året efter. Andelar i procent

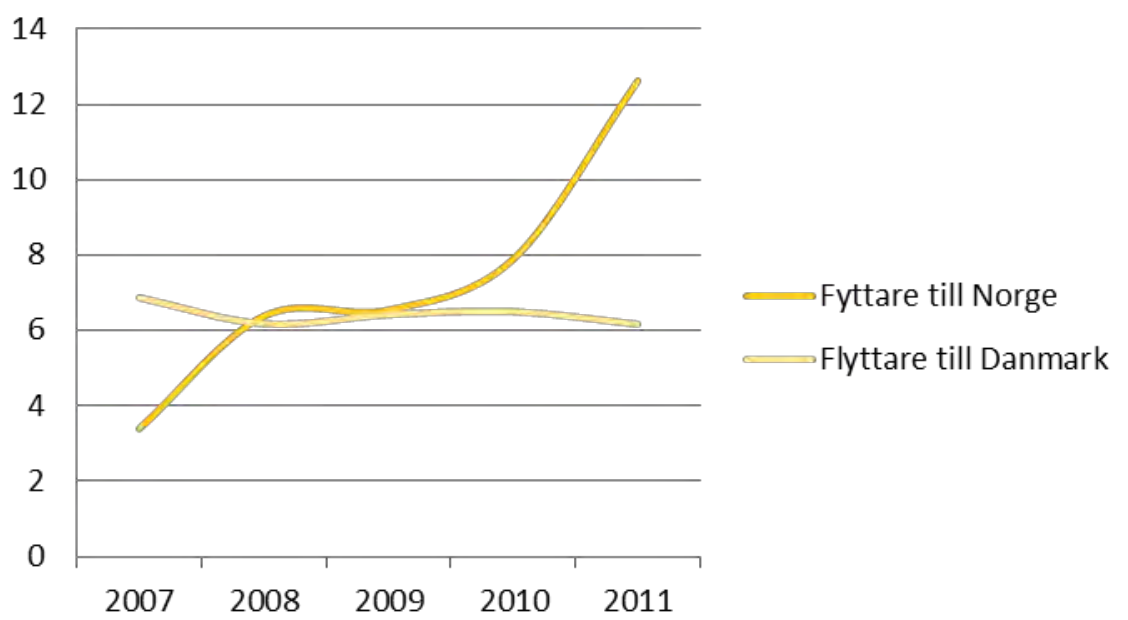

\subsection{Normänn och danskar som flyttar till Sverige har inte pendlat innan}

Under 2009 har en stor del av de som invandrat till Sverige, kommit från Norge eller Danmark (4 500 respektive 4800 personer från 15 år och äldre). Väldigt få av dessa personer har tidigare gränspendlat till Sverige. Av de inflyttade norrmännen var 37 procent förvärvsarbetande i Sverige det påföljande året, medan det för danskarnas del var 18 procent. Hela 26 procent jobbade istället kvar i Danmark, de blev till följd av flytten gränspendlare från Sverige till Danmark.

Från Norge har de senaste åren nästan 1000 personer gränspendlat till Sverige varje år och något fler, omkring 1000 till 2000 personer kom från Danmark. Omkring 10-13 procent av arbetspendlarna från Norge och omkring 5-10 procent av danskarna valde att efter ett år av pendling flytta till Sverige enligt diagram 11. De flesta danskar och norrmän som skaffat jobb i Sverige flyttar omgående till det nya arbetslandet. 


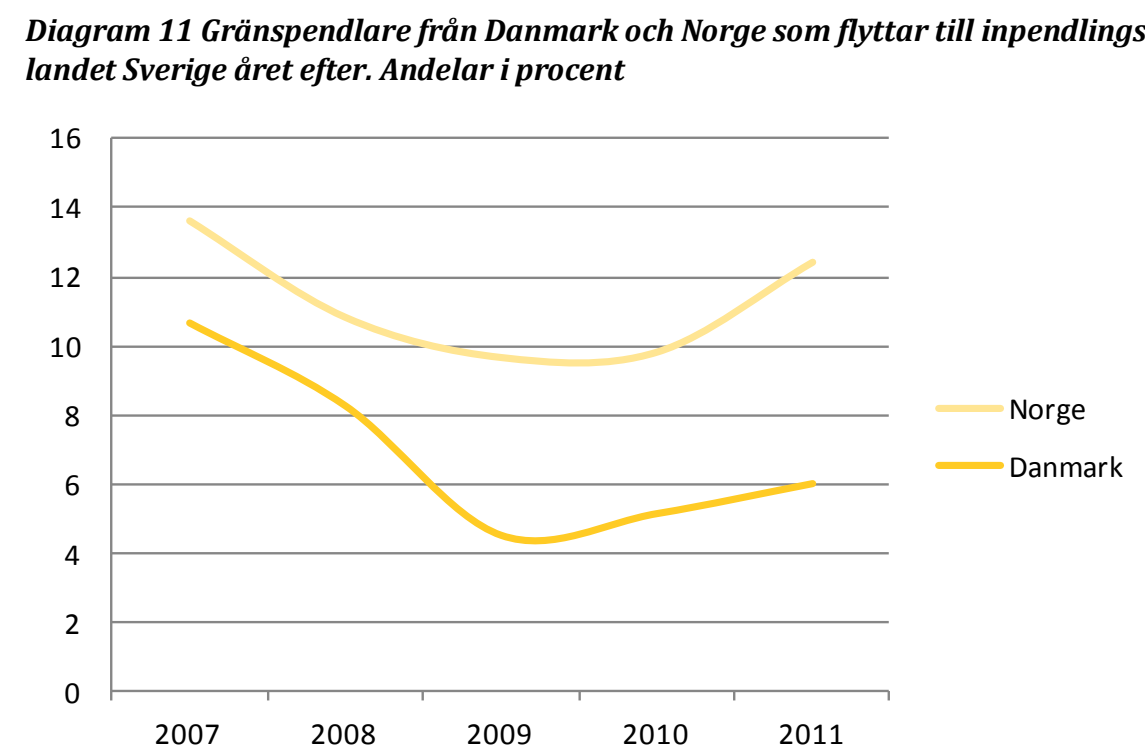

Statistik som beskriver gränspendlinges koppling till flyttningar mellan Danmark och Norge saknas för närvarande. Likaså saknar vi i dagsläget underlag som ger svar på de svenska emigranternas egenskaper och arbetsmarknadsstatus i Danmark och Norge. Vi hoppas dock på att få möjligheter att utveckla statistiksamarbete mellan länderna så att vi kan göra sådana beskrivningar.

\subsection{De fătaliga norska och danska gränspendlare som trots allt flyttar till jobbet i Sverige efter ett år är ofta födda i Sverige}

7 procent av gränspendlarna från Norge till Sverige år 2010 flyttade till ett jobb i Sverige år 2010 och 80 procent av dem var födda i Sverige. Av de danska gränspendlarna till Sverige flyttade knappt 4 procent till ett jobb i Sverige och två tredjedelar var födda i Sverige.

Sammanfattningsvis kan vi konstatera att gränspendlare i liten omfattning flyttar till arbetslandet efter ett år, oavsett i vilket land man arbetar och bor i, även om vi de senaste åren sett en ökande andel svenska ungdomar som efter en tids gränspendling flyttar till Norge. 



\section{Kartbilaga}

\section{Arbetspendling till norska kommuner från Danmark samt Sverige}

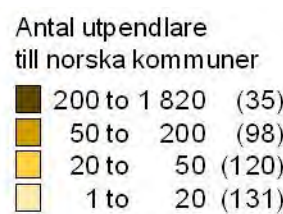

Antal inpendlare till norska kommuner

$\square 300$ to 11400 (16)

100 to $300 \quad(28)$

20 to $100 \quad(98)$

1 to $20(256)$
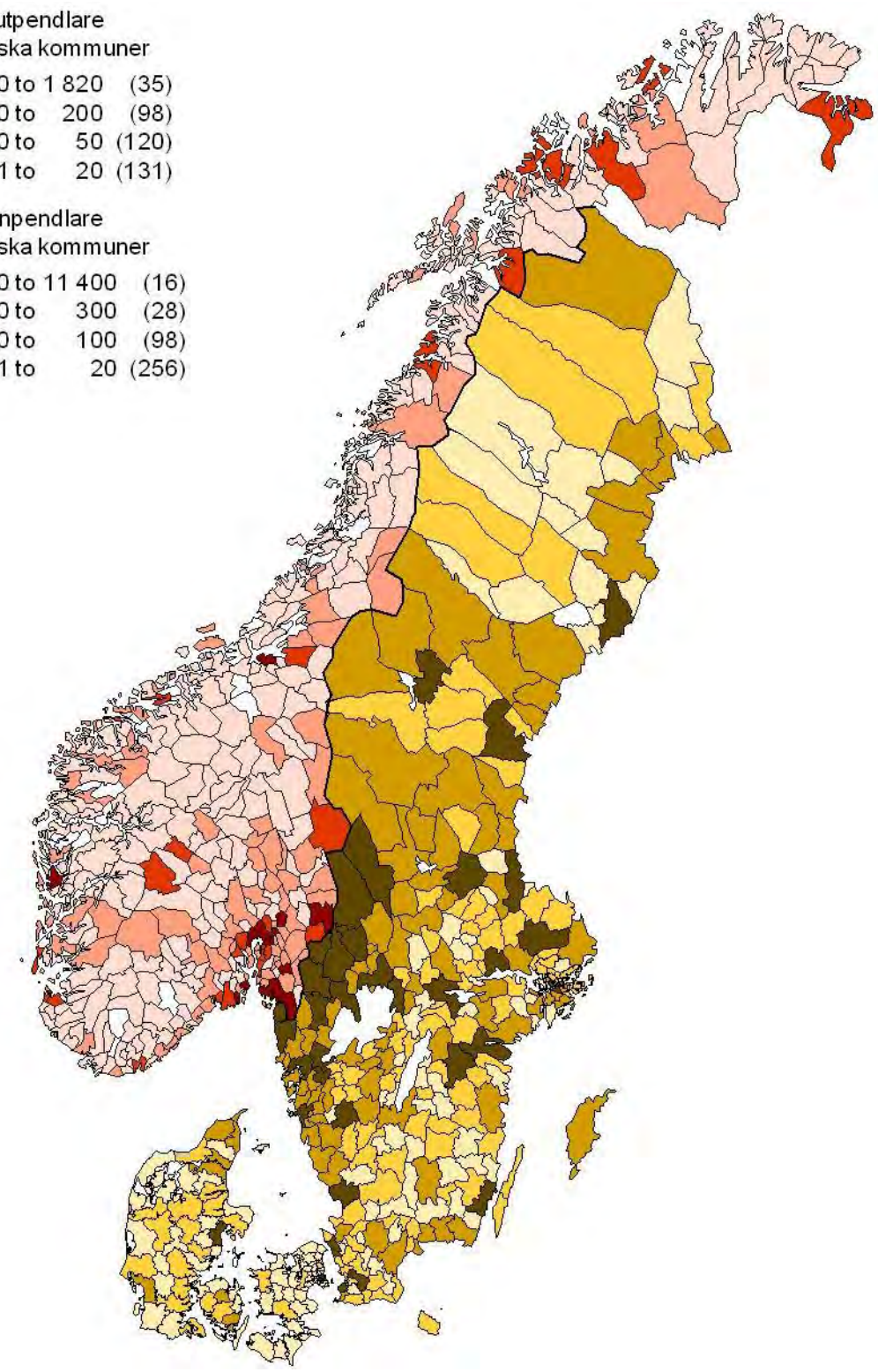

Nordisk pendlingskarta 2009. 


\section{Arbetspendling till danska kommuner från Norge samt Sverige}

Antal utpendlare
till danska kommuner
$\begin{array}{rrr}200 \text { to } 11 & 300 & (11) \\ 100 \text { to } & 200 & (14) \\ 5 \text { to } & 100 & (69) \\ 1 \text { to } & 5 & (208)\end{array}$

Antal inpendlare till danska kommuner

300 to $8400(14)$

50 to $300(17)$

20 to $50(16)$

1 to $20(47)$

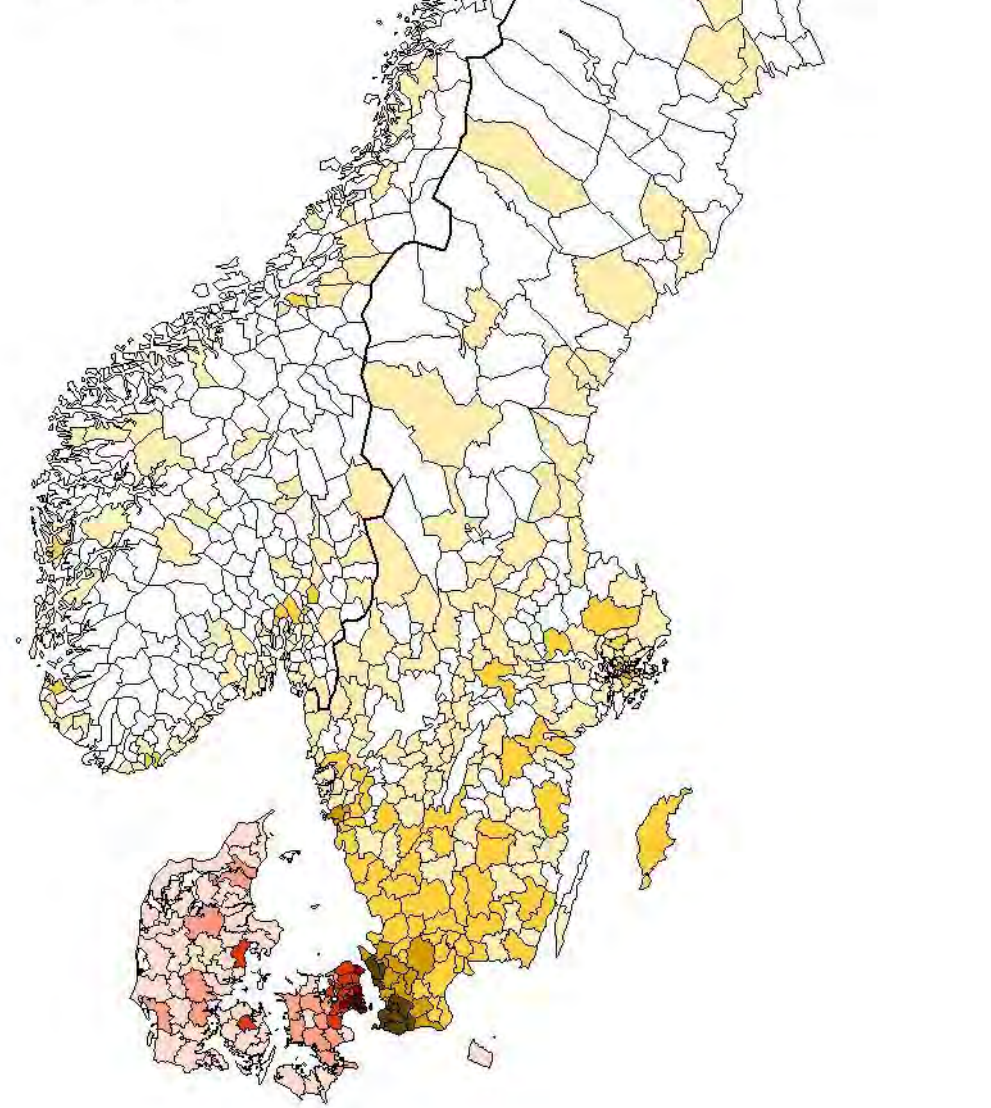

Nordisk pendlingskarta 2009. 


\section{Arbetspendling till svenska kommuner från Norge samt Danmark}

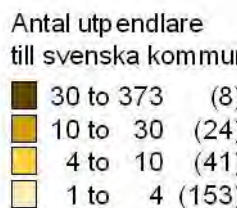

Antal inpendlare

till svenska kommuner

40 to 340 (6)

10 to $40(15)$

5 to $10(30)$

1 to $5(99)$

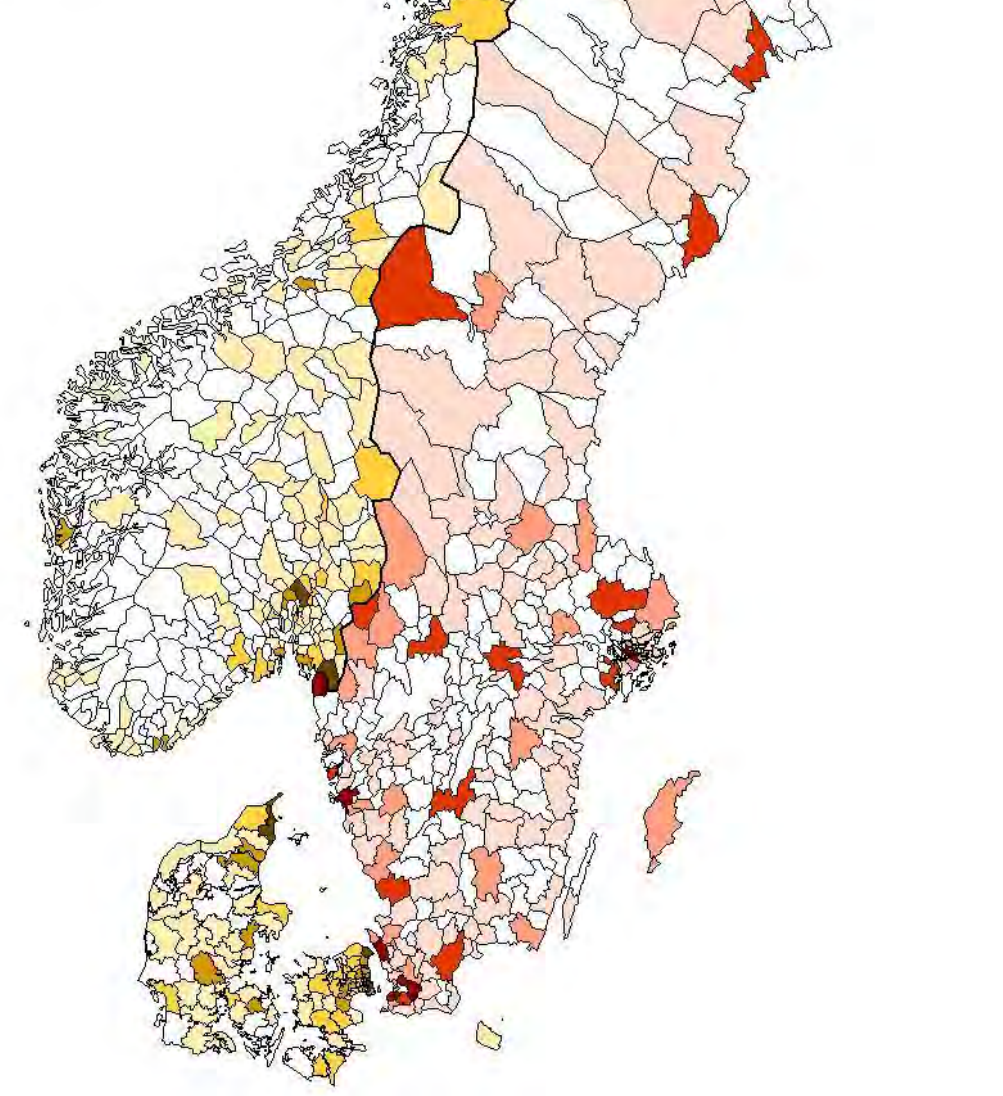

Nordisk pendlingskarta 2009. 


\section{Lokala arbetsmarknader över riksgräns, 2009}

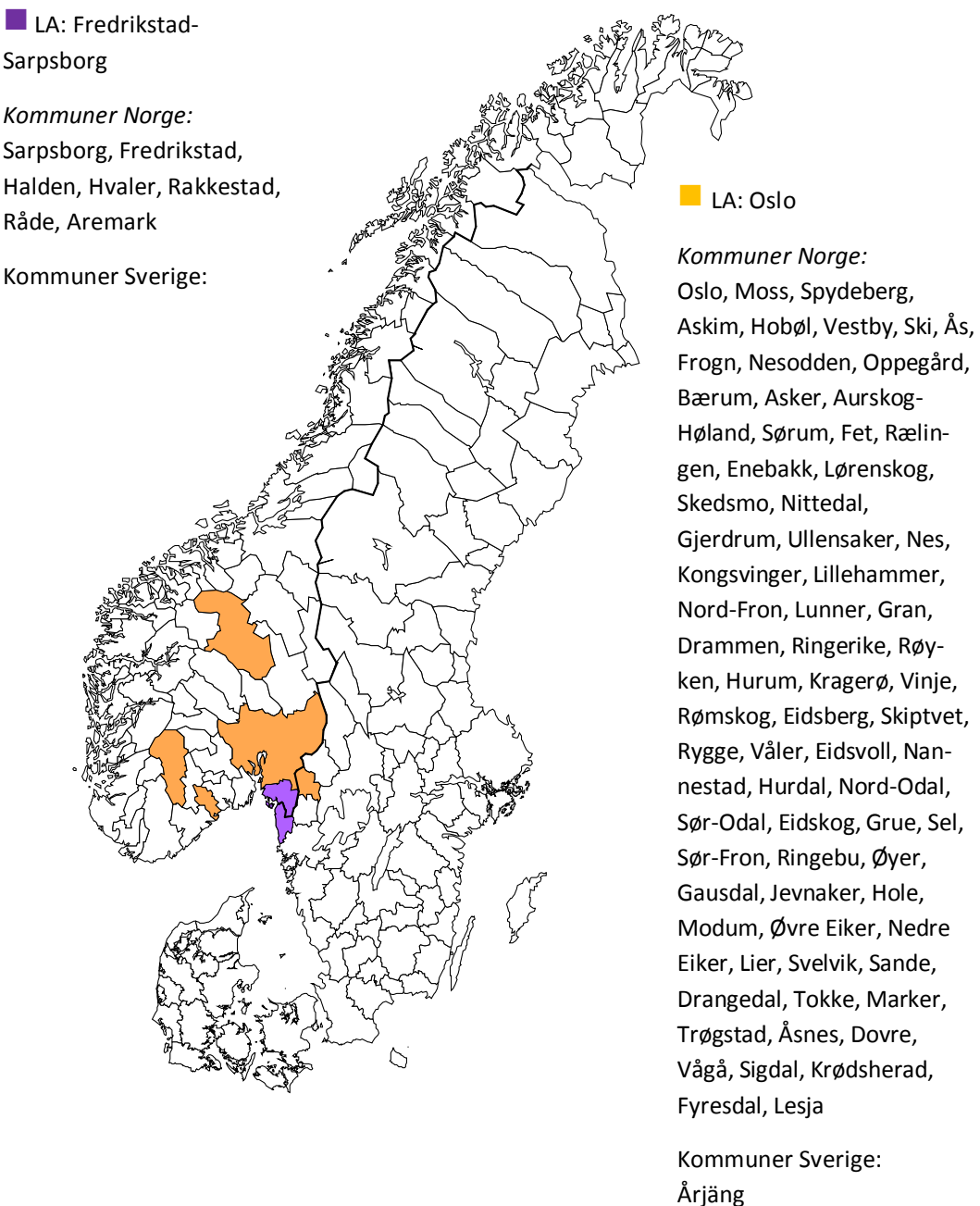

Nordisk pendlingskarta 2009

Lokala arbetsmarknader är funktionella regioner som beskriver ett område som är relativt oberoende av omvärlden med avseende på utbud och efterfrågan av arbetskraft. En lokal arbetsmarknad är inte statisk utan kan förändras över tiden beroende på pendlingsströmmarnas riktning och styrka. Läs mer om lokala arbetsmarknader i SCB-rapporten "Lokala arbetsmarknader - egenskaper, struktur och utveckling" på www.scb.se/rams 


\section{Summary}

The sharp expansion of Swedish cross-border commuting to Denmark and Norway slowed down in 2009. 600 fewer Swedes cross-border commuted to Denmark, while the increase to Norway was "only" 2,000 persons, implying a total change of roughly 3 percent compared to 2008. The annual increases for 2006-2008 were nearly 20 percent or about 7,000 persons per year.

The Danish cross-border commuting to Norway and Sweden was at the same level, while the Norwegian cross-border commuting to Denmark and Sweden decreased by 20 percent.

Since 2001, cross-border commuting increased from 24,800 to 53,700 persons, an upswing of nearly 120 percent.

Finland was also included in the statistics during 2004-2006, implying that another 6,000 cross-border commuters were also included then. It is likely that close to 70,000 residents of the Nordic countries were cross-border commuters during 2009.

\section{Cross-border commuting is not gender-equal}

The proportion of women who were cross-border commuters increased by one percentage point to 36 percent during 2009. This does not reach the goal that is usually given for gender equality of $40 / 60$ percent. Two commuting flows can be seen as gender-equal: The some 20,000 commuters from Sweden to Denmark and the roughly 3,100 commuters from Denmark to Norway. In both cases the proportion of women is around 40 percent.

\section{Many cross-border commute to their countries of origin}

In 2009 nearly 40 percent of the Danish cross-border commuters to Norway and Sweden were born in those countries. Among Danish women who commuted to Norway, an entire 71 percent were born in Norway. Of the Swedish cross-border commuters to Denmark, 30 percent of the women and 40 percent of the men were born in Denmark. As a result, somewhat more Danish-born men commuted from Sweden to Denmark than Swedish-born men. 


\section{Cross-border commuting is limited to a few industries}

The EU industrial classification NACE Rev. 2 includes 21 divisions/industries at the one-letter level. Roughly three fourths of the commuters had jobs within seven of these industries. 17 percent of all commuters worked within the industry for staffing services. This was followed by trade; repairs for motor vehicles and motorcycles accounted for about 13 percent. Other relatively large industries included Building and Construction, Transport and warehousing, Manufacturing and Healthcare. Cross-border commuting from Norway and Denmark was mainly for jobs within trade, while staffing services were the most significant for Sweden's share of commuters.

\section{Some industries are highly dependent on inbound commuting for their labour force supply}

A region's competitiveness and growth depends on a competent labour force that matches the needs of the region's enterprises and public organisations. To maintain the labour force supply, many regions are in need of significant inbound commuting.

Cross-border commuters comprised more than 15 percent of the gainfully employed persons within a certain industry in thirteen Norwegian municipalities and one Danish municipality. In the Danish municipality of Tårnby, this industry was Transport and warehousing. In Hemsedal, Trysil and Nol in Norway, many employees within the Hotel and restaurant industry were commuters. Staffing services employed persons to a considerable extent from the neighbouring countries in five of the eleven municipalities.

\section{SEK 25 billion in salaries}

In 2009 a total of 99,000 salaried employees worked in another country. Roughly half of these persons commuted to their main job in the neighbouring country. Salaries totalled SEK 25 billion, an increase of 200 percent in current prices compared to 2001. Adjusted for inflation the increase were 166 percent. Roughly SEK 22 billion was earned by Swedes in Denmark and Norway.

\section{More Swedish young people now move to jobs in Norway}

During the 1960s and 1970s people normally emigrated to the country they worked in. During the 2000s people have to a greater extent chosen to reside in their home country and commute to the neighbouring country. 12 percent of the Norwegians who cross-border commuted to Sweden in 2009 moved there in 2010. The corresponding figure for Danes who moved to Sweden was 6 percent. Meanwhile, 6 percent of the 
Swedes moved to Denmark and 8 percent moved to Norway. New figures show that 12 percent of the Swedish cross-border commuters in 2010 moved to Norway in 2011. This is twice as high a percentage compared to 2008. It is the young people aged 15-24 who move.

Statistics that describe the connection of moves between Denmark and Norway are not being produced at this time. 



\section{Bilaga 1. Metodbeskrivning}

I Sverige, Norge och Danmark finns en registerbaserad sysselsättningsstatistik som är likartat uppbyggd och kan användas för att beskriva integrationen på den nordiska arbetsmarknaden. Metoden utgår från personer som finns registrerade med inkomst i arbetslandet men som saknas i centrala personregister. Dessa personer har anställning i arbetslandet och är inte folkbokförda i landet i fråga. Genom att utbyta uppgifter om dessa personer mellan två länder är det möjligt att identifiera personernas bostadsland. Resultatet blir en grupp människor som bor i ett land och har löneinkomst i ett annat. Från denna grupp kan man därefter utifrån särskilda kriterier avskilja personer som betraktas som arbetspendlare över riksgräns.

Det finns flera syften med att belysa antalet personer som arbetar i ett land och bor i ett annat:

- Mått på integrationen mellan länderna.

- Rörligheten på nordisk arbetsmarknad.

- Flödet av arbetsinkomster mellan länderna.

- Förbättra den nationella sysselsättningsstatistiken. De personer som arbetar i ett land och bor i ett annat kommer inte med i arbetslandets statistik och redovisas som ej förvärvsarbetande i bostadslandets statistik.

- Fördjupa jämförelserna mellan de nordiska ländernas arbetsmarknader.

\section{Personnummer och matchning}

De nordiska länderna har väl utbyggda administrativa system för bl.a. folkbokföring och taxering. I dessa system identifieras personer med unika personnummer. Numren är olika konstruerade i de olika länderna, varför det inte utan vidare går att matcha på personnummer mellan ländernas register. Däremot finns uppgifter om födelsedatum, kön och namn registrerade i registren. Genom att kombinera dessa uppgifter är det möjligt att göra jämförelser mellan de uppgifter som finns om de aktuella personerna i båda ländernas register. Då namnregistrering kan ske på olika sätt i respektive land, t.ex. genom annorlunda stavning eller olika antal förnamn, är systemet inte helt vattentätt. Även efter manuella 
genomgångar där namnuppsättningar jämförs kan det hända att ett fåtal personer inte betraktas som matchande och därför inte kommer med i statistiken fast de borde ha räknats med. Genom EU:s fria rörlighet på arbetsmarknaden har många arbetstagare möjlighet att på korttidsbasis arbeta i annat EU-land utan att vara anställd av arbetsgivare eller betala inkomstskatt i arbetslandet. Dessa personer behöver då, för några inte registreras i några administrativa register och kommer därför inte att räknas med i statistiken.

\section{Sekretess}

Utbyte av sekretessbelagt material kan under vissa omständigheter utbytas mellan statistikmyndigheter efter särskilda prövningar. Utlämnandeprövning ur sekretessynpunkt har skett vid respektive statistikmyndighet eller av därför särskilt utsedd funktion i landet. Vid denna prövning har värdet av att få en statistisk bild av arbetsflöden mellan de nordiska länderna och att åstadkomma en förbättrad statistik i respektive land vägts mot det faktum att materialet överlämnas till en annan nordisk statistikmyndighet. I samtliga fall har tillstånd getts för utlämning av material. Resultaten publiceras enbart i form av tabeller där enskilda personer inte kan identifieras, vilket begränsar möjligheterna att använda statistiken i analyser m.m.

\section{Sambearbetning av registerinformation}

\section{Steg 1. Identifiering av eventuella arbetspendlare}

Först identifieras den grupp av personer som haft en anställning med inkomst i arbetslandet (land A), men som inte är folkbokförda i land $\mathrm{A}$ den 31 december aktuellt kalenderår. Denna grupp har ofta ett personnummer som avviker från det vanliga personnumret. Födelsedatum går dock att utläsa utifrån detta speciella personnummer. För att senare kunna fullfölja datautbytet kopplas dessutom ett informationslöst löpnummer till varje person. Därefter sänds ett dataset med den aktuella populationen innehållande födelsedatum och namn till mottagande land B (bostadslandet).

\section{Steg 2. Utlämnande av bakgrunds- och arbetsmarknadsdata data från den eventuella bostadslandet (land $\mathrm{B}$ )}

I bostadslandet (land B) matchas födelsedatum och namn mot befolkningsregistret för att se vilka som är folkbokförda där. För de personer som identifierats i bostadslandet framställs ett dataset med demo- 
grafiska uppgifter och uppgifter om person även har ett arbete i bostadslandet. Detta material lämnas till arbetslandet och omfattar de personer som återfunnits som folkbokförda i land B och som haft arbete i land A. Därmed vet man hur många personer som bor i land $\mathrm{B}$ och som haft en anställning i land $\mathrm{A}$.

\section{Steg 3. Komplettering med data från arbetslandet (land A)}

När materialet återkommer till arbetslandet kompletteras det med data om personernas arbete i arbetslandet. Därmed är det möjligt att avgöra i vilket land som personernas huvudsakliga arbete bedrivits. Utifrån dessa uppgifter fastställs vilka personer som skall klassificeras som arbetspendlare över riksgräns.

\section{Steg 4. Ett komplett material sänds åter till bostadslandet (land B)}

I och med att bostadslandet också får det färdiga materialet så har båda länderna gemensam information om den aktuella populationen. Statistikmyndigheterna i respektive land kan därefter självständigt avgöra hur den nya och unika informationen ska användas för nationell beskrivning av det egna landets sysselsättningssituation.

\section{Löntagare med inkomst i annat land}

Begreppet inkomsttagare med inkomst i ett annat land omfattar dels de personer som klassats som arbetspendlare över riksgräns, dels övriga löntagare med inkomst i det andra landet.

Detta begrepp ger en helhetsbild av flödet av arbetsinkomster över en riksgräns.

\section{Arbetpendlare över riksgräns, klassificering}

För att räknas som arbetspendlare över riksgräns ska den aktuella personen inneha ett jobb som täcker november månad i arbetslandet under det aktuella året. Dessutom krävs att personen uppnår en inkomstnivå motsvarande 4 timmars arbete för denna månad. Slutligen skall inkomsten överstiga inkomsten i hemlandet för samma kalenderår.

När steg 3 är genomfört finns underlag för att bestämma vilka inkomsttagare som ska klassificeras som arbetspendlare över riksgräns. Detta avgränsningsarbete görs i arbetslandet där man också framställer de tabeller som skall användas vid statistikredovisningen. 


\section{Förändringar mellan SNI 2002 och SNI 2007}

SNI 2002 hade 17 avdelningar och 62 huvudgrupper, SNI 2007 har 21 avdelningar och 88 huvudgrupper. På gruppnivå har antalet klasser ökat från 224 till 272 och på undergruppsnivå från 514 till 615 klasser. På detaljgruppsnivå har antalet klasser ökat från 776 till 821. För utförligare information se mis 2007:2 SNI2007 Standard för svensk näringsgrensindelning 2007.

Tabellen visar endast en grov överensstämmelse mellan avdelningarna. 


\begin{tabular}{|c|c|c|c|}
\hline SNI 2002 & & SNI 2007 & \\
\hline Avdelning & Benämning & Avdelning & Benämning \\
\hline A & Jordbruk, jakt och skogsbruk & A & Jordbruk, skogsbruk och fiske \\
\hline B & Fiske & & \\
\hline C & Utvinning av mineral & B & Utvinning av mineral \\
\hline D & Tillverkning & C & Tillverkning \\
\hline \multirow[t]{2}{*}{$\mathrm{E}$} & El-, gas-, värme- och vattenförsörjning & D & Försörjning av el, gas, värme och kyla \\
\hline & & $\mathrm{E}$ & $\begin{array}{l}\text { Vattenförsörjning; avloppsrening, } \\
\text { avfallshantering och sanering }\end{array}$ \\
\hline $\mathrm{F}$ & Byggverksamhet & $\mathrm{F}$ & Byggverksamhet \\
\hline G & $\begin{array}{l}\text { Partihandel och detaljhandel; } \\
\text { reparation av motorfordon, hushålls- } \\
\text { artiklar och personliga artiklar }\end{array}$ & G & $\begin{array}{l}\text { Handel; reparation av motorfordon och } \\
\text { motorcyklar }\end{array}$ \\
\hline $\mathrm{H}$ & Hotell- och restaurangverksamhet & 1 & Hotell- och restaurangverksamhet \\
\hline \multirow[t]{2}{*}{ I } & $\begin{array}{l}\text { Transport, magasinering och } \\
\text { kommunikation }\end{array}$ & $\mathrm{H}$ & Transport och magasinering \\
\hline & & J & $\begin{array}{l}\text { Informations- och } \\
\text { kommunikationsverksamhet }\end{array}$ \\
\hline $\mathrm{J}$ & Finansiell verksamhet & K & Finans- och försäkringsverksamhet \\
\hline \multirow[t]{3}{*}{ K } & $\begin{array}{l}\text { Fastighets- och uthyrningsverksam- } \\
\text { het, företagstjänster }\end{array}$ & $\mathrm{L}$ & Fastighetsverksamhet \\
\hline & & M & $\begin{array}{l}\text { Verksamhet inom juridik, ekonomi, } \\
\text { vetenskap och teknik }\end{array}$ \\
\hline & & $\mathrm{N}$ & $\begin{array}{l}\text { Uthyrning, fastighetsservice, } \\
\text { resetjänster och andra stödtjänster }\end{array}$ \\
\hline L & $\begin{array}{l}\text { Offentlig förvaltning och försvar; } \\
\text { obligatorisk socialförsäkring }\end{array}$ & 0 & $\begin{array}{l}\text { Offentlig förvaltning och försvar; } \\
\text { obligatorisk socialförsäkring }\end{array}$ \\
\hline M & Utbildning & $\mathrm{P}$ & Utbildning \\
\hline $\mathrm{N}$ & $\begin{array}{l}\text { Hälso- och sjukvård, sociala tjänster; } \\
\text { veterinärverksamhet }\end{array}$ & Q & Vård och omsorg; sociala tjänster \\
\hline \multirow[t]{2}{*}{0} & $\begin{array}{l}\text { Andra samhälleliga och } \\
\text { personliga tjänster }\end{array}$ & $\mathrm{R}$ & Kultur, nöje och fritid \\
\hline & & $\mathrm{S}$ & Annan serviceverksamhet \\
\hline$P$ & Hushållens verksamhet & $\mathrm{T}$ & $\begin{array}{l}\text { Förvärvsarbete i hushåll; hushållens } \\
\text { produktion av diverse varor och tjänster } \\
\text { för eget bruk }\end{array}$ \\
\hline Q & $\begin{array}{l}\text { Verksamhet vid internationella } \\
\text { organisationer, utländska ambassa- } \\
\text { der o.d. }\end{array}$ & $\mathrm{U}$ & $\begin{array}{l}\text { Verksamhet vid internationella organi- } \\
\text { sationer, utländska ambassader o.d }\end{array}$ \\
\hline
\end{tabular}





\section{Bilaga 2. Största inpendlings- bransch för kommuner som tar emot mer än $\mathbf{5 0}$ gränspendlare}




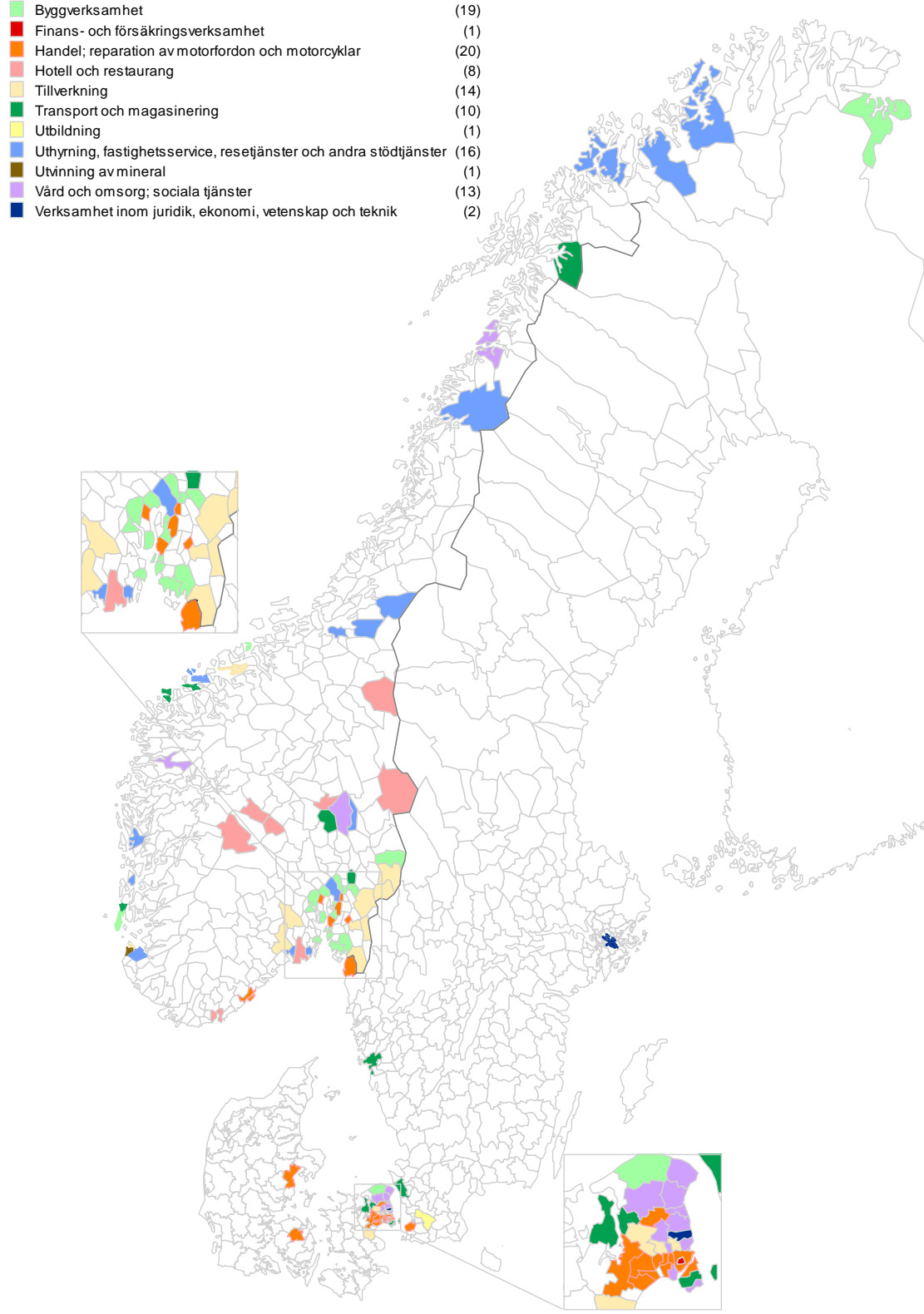




\section{Tabellbilaga}

\begin{tabular}{|c|c|}
\hline Tabell 1a & Antal danska arbetspendlare efter ålder och kön 2009 \\
\hline Tabell 1aa & Förändring av antal danska arbetspendlare 2009 jämfört med 2008 efter ålder och kön \\
\hline Tabell 1b & Antal norska arbetspendlare efter ålder och kön 2009 \\
\hline Tabell $1 \mathrm{bb}$ & Förändring av antal norska arbetspendlare 2009 jämfört med 2008 efter ålder och kön \\
\hline Tabell 1c & Antal svenska arbetspendlare efter ålder och kön 2009 \\
\hline Tabell 1cc & Förändring av antal svenska arbetspendlare 2009 jämfört med 2008 efter ålder och kön \\
\hline Tabell 2a & Antal danska arbetspendlare efter födelseregion och kön 2009 \\
\hline Tabell 2aa & Förändring av antal danska arbetspendlare 2009 jämfört med 2008 efter födelseregion och kön \\
\hline Tabell 2b & Antal norska arbetspendlare efter födelseregion och kön 2009 \\
\hline Tabell $2 \mathrm{bb}$ & Förändring av antal norska arbetspendlare 2009 jämfört med 2008 efter födelseregion och kön \\
\hline Tabell 2c & Antal svenska arbetspendlare efter födelseregion och kön 2009 \\
\hline Tabell 2cc & Förändring av antal svenska arbetspendlare 2009 jämfört med 2008 efter födelseregion och kön \\
\hline Tabell 3a & Antal danska arbetspendlare efter utbildningsnivå och kön 2009 \\
\hline Tabell 3aa & Förändring av antal danska arbetspendlare 2009 jämfört med 2008 efter utbildningsnivå och kön \\
\hline Tabell 3b & Antal norska arbetspendlare efter utbildningsnivå och kön 2009 \\
\hline Tabell 3bb & Förändring av antal norska arbetspendlare 2009 jämfört med 2008 efter utbildnings`nivå och kön \\
\hline Tabell 3c & Antal svenska arbetspendlare efter utbildningsnivå och kön 2009 \\
\hline Tabell 3cc & Förändring av antal svenska arbetspendlare 2009 jämfört med 2008 efter utbildningsnivå och kön \\
\hline Tabell 4a & Antal danska arbetspendlare efter sektor och kön 2009 \\
\hline Tabell 4aa & Förändring av antal danska arbetspendlare 2009 jämfört med 2008 efter sektor och kön \\
\hline Tabell 4b & Antal norska arbetspendlare efter sektor och kön 2009 \\
\hline Tabell $4 \mathrm{bb}$ & Förändring av antal norska arbetspendlare 2009 jämfört med 2008 efter sektor och kön \\
\hline Tabell 4c & Antal svenska arbetspendlare efter sektor och kön 2009 \\
\hline Tabell 4cc & Förändring av antal svenska arbetspendlare 2009 jämfört med 2008 efter sektor och kön \\
\hline Tabell 5a & Antal danska arbetspendlare efter näringsgren och kön 2009 \\
\hline Tabell 5aa & Förändring av antal danska arbetspendlare 2009 jämfört med 2008 efter näringsgren och kön \\
\hline Tabell 5b & Antal norska arbetspendlare efter näringsgren och kön 2009 \\
\hline Tabell $5 b b$ & Förändring av antal norska arbetspendlare 2009 jämfört med 2008 efter näringsgren och kön \\
\hline Tabell 5c & Antal svenska arbetspendlare efter näringsgren och kön 2009 \\
\hline Tabell 5cc & Förändring av antal svenska arbetspendlare 2009 jämfört med 2008 efter näringsgren och kön \\
\hline
\end{tabular}


Tabell 1a. Antal danska arbetspendlare efter ålder och kön 2009

\begin{tabular}{|c|c|c|c|c|c|c|c|c|c|}
\hline \multicolumn{4}{|c|}{ Totalt antal danska arbetspendlare } & \multicolumn{6}{|c|}{ Därav till } \\
\hline \multirow[b]{2}{*}{ Ålder } & \multirow[b]{2}{*}{ Totalt } & \multirow[b]{2}{*}{ Män } & \multirow[b]{2}{*}{ Kv } & \multicolumn{3}{|c|}{ Norge } & \multicolumn{3}{|c|}{ Sverige } \\
\hline & & & & Totalt & Män & Kv & Totalt & Män & Kv \\
\hline Alla åldrar & 4261 & 2656 & 1605 & 3132 & 1893 & 1239 & 1129 & 763 & 366 \\
\hline 15-19 & 93 & 20 & 73 & 88 & 17 & 71 & 5 & 3 & 2 \\
\hline $20-24$ & 1012 & 356 & 656 & 970 & 335 & 635 & 42 & 21 & 21 \\
\hline $25-54$ & 2472 & 1776 & 696 & 1683 & 1242 & 441 & 789 & 534 & 255 \\
\hline $55-64$ & 535 & 398 & 137 & 315 & 248 & 67 & 220 & 150 & 70 \\
\hline 65- & 149 & 106 & 43 & 76 & 51 & 25 & 73 & 55 & 18 \\
\hline
\end{tabular}

Tabell 1aa. Förändring av antal danska arbetspendlare 2009 jämfört med 2008 efter ålder och kön

Procentuell förändring av
danska arbetspendlare

Tabell 1b. Antal norska arbetspendlare efter ålder och kön 2009

\begin{tabular}{|c|c|c|c|c|c|c|c|c|c|}
\hline \multicolumn{4}{|c|}{ Totalt antal norska arbetspendlare } & \multicolumn{6}{|c|}{ Därav till } \\
\hline \multirow[b]{2}{*}{ Ålder } & \multirow[b]{2}{*}{ Totalt } & \multirow[b]{2}{*}{ Män } & \multirow[b]{2}{*}{ Kv } & \multicolumn{3}{|c|}{ Danmark } & \multicolumn{3}{|c|}{ Sverige } \\
\hline & & & & Totalt & Män & Kv & Totalt & Män & Kv \\
\hline Alla åldrar & 1158 & 755 & 403 & 325 & 232 & 93 & 833 & 523 & 310 \\
\hline $15-19$ & 113 & 49 & 64 & 9 & 2 & 7 & 104 & 47 & 57 \\
\hline $20-24$ & 109 & 50 & 59 & 33 & 16 & 17 & 76 & 34 & 42 \\
\hline $25-54$ & 737 & 515 & 222 & 256 & 196 & 60 & 481 & 319 & 162 \\
\hline $55-64$ & 157 & 111 & 46 & 22 & 16 & 6 & 135 & 95 & 40 \\
\hline $65-$ & 42 & 30 & 12 & 5 & 2 & 3 & 37 & 28 & 9 \\
\hline
\end{tabular}

Tabell 1bb. Förändring av antal norska arbetspendlare 2009 jämfört med 2008 efter ålder och kön

\begin{tabular}{|c|c|c|c|c|c|c|c|c|c|}
\hline \multicolumn{4}{|c|}{$\begin{array}{l}\text { Procentuell förändring av } \\
\text { norska arbetspendlare }\end{array}$} & \multicolumn{6}{|c|}{ Därav till } \\
\hline \multirow[b]{2}{*}{ Ålder } & \multirow[b]{2}{*}{ Totalt } & \multirow[b]{2}{*}{ Män } & \multirow[b]{2}{*}{ Kv } & \multicolumn{3}{|c|}{ Danmark } & \multicolumn{3}{|c|}{ Sverige } \\
\hline & & & & Totalt & Män & Kv & Totalt & Män & Kv \\
\hline Alla åldrar & $-20,5$ & $-15,5$ & $-28,5$ & $-17,5$ & 1,8 & $-44,0$ & $-21,6$ & $-21,4$ & $-22,1$ \\
\hline $15-19$ & $-19,3$ & $-3,9$ & $-28,1$ & $-35,7$ & 0,0 & $-41,7$ & $-17,5$ & $-4,1$ & $-26,0$ \\
\hline $20-24$ & $-32,3$ & $-26,5$ & $-36,6$ & $-44,1$ & 0,0 & $-60,5$ & $-25,5$ & $-34,6$ & $-16,0$ \\
\hline $25-54$ & $-21,8$ & $-15,7$ & $-32,9$ & $-12,0$ & 5,4 & $-42,9$ & $-26,1$ & $-24,9$ & $-28,3$ \\
\hline $55-64$ & $-11,3$ & $-17,2$ & 7,0 & $-18,5$ & $-23,8$ & 0,0 & $-10,0$ & $-15,9$ & 8,1 \\
\hline $65-$ & 13,5 & 3,4 & 50,0 & 66,7 & $-33,3$ & .. & 8,8 & 7,7 & 12,5 \\
\hline
\end{tabular}


Tabell 1c. Antal svenska arbetspendlare efter ålder och kön 2009

\begin{tabular}{|c|c|c|c|c|c|c|c|c|c|}
\hline \multicolumn{4}{|c|}{ Totalt antal svenska arbetspendlare } & \multicolumn{6}{|c|}{ Därav till } \\
\hline \multirow[b]{2}{*}{ Ålder } & \multirow[b]{2}{*}{ Totalt } & \multirow[b]{2}{*}{ Män } & \multirow[b]{2}{*}{ Kv } & \multicolumn{3}{|c|}{ Danmark } & \multicolumn{3}{|c|}{ Norge } \\
\hline & & & & Totalt & Män & Kv & Totalt & Män & Kv \\
\hline Alla åldrar & 48330 & 31079 & 17251 & 20189 & 11949 & 8240 & 28141 & 19130 & 9011 \\
\hline $15-19$ & 1326 & 599 & 727 & 295 & 100 & 195 & 1031 & 499 & 532 \\
\hline $20-24$ & 10710 & 5386 & 5324 & 2309 & 994 & 1315 & 8401 & 4392 & 4009 \\
\hline $25-54$ & 31742 & 21934 & 9808 & 16035 & 9886 & 6149 & 15707 & 12048 & 3659 \\
\hline $55-64$ & 3920 & 2739 & 1181 & 1423 & 883 & 540 & 2497 & 1856 & 641 \\
\hline $65-$ & 632 & 421 & 211 & 127 & 86 & 41 & 505 & 335 & 170 \\
\hline
\end{tabular}

Tabell 1cc. Förändring av antal svenska arbetspendlare 2008 jämfört med 2009 efter ålder och kön

\begin{tabular}{|c|c|c|c|c|c|c|c|c|c|}
\hline \multicolumn{4}{|c|}{$\begin{array}{l}\text { Procentuell förändring av } \\
\text { svenska arbetspendlare }\end{array}$} & \multicolumn{6}{|c|}{ Därav till } \\
\hline \multirow[b]{2}{*}{ Ålder } & \multirow[b]{2}{*}{ Totalt } & \multirow[b]{2}{*}{ Män } & \multirow[b]{2}{*}{ Kv } & \multicolumn{3}{|c|}{ Danmark } & \multicolumn{3}{|c|}{ Norge } \\
\hline & & & & Totalt & Män & Kv & Totalt & Män & Kv \\
\hline Alla åldrar & 2,8 & 2,0 & 4,1 & $-3,0$ & $-3,5$ & $-2,3$ & 7,3 & 5,8 & 10,8 \\
\hline $15-19$ & $-30,8$ & $-29,6$ & $-31,8$ & $-44,4$ & $-54,8$ & $-37,1$ & $-25,6$ & $-20,8$ & $-29,6$ \\
\hline $20-24$ & 0,3 & $-1,8$ & 2,6 & $-16,8$ & $-16,5$ & $-16,9$ & 6,3 & 2,2 & 11,2 \\
\hline $25-54$ & 4,8 & 3,6 & 7,5 & $-0,2$ & $-1,6$ & 2,1 & 10,4 & 8,3 & 18,0 \\
\hline $55-64$ & 8,2 & 5,8 & 14,3 & 6,6 & 4,5 & 10,2 & 9,2 & 6,4 & 18,0 \\
\hline $65-$ & 19,9 & 13,5 & 35,3 & 23,3 & 13,2 & 51,9 & 19,1 & 13,6 & 31,8 \\
\hline
\end{tabular}

Tabell 2a. Antal danska arbetspendlare efter födelseregion och kön 2009

\begin{tabular}{|c|c|c|c|c|c|c|c|c|c|}
\hline \multicolumn{4}{|c|}{ Totalt antal danska arbetspendlare } & \multicolumn{6}{|c|}{ Därav till } \\
\hline \multirow[b]{2}{*}{ Födelseregion } & \multirow[b]{2}{*}{ Totalt } & \multirow[b]{2}{*}{ Män } & \multirow[b]{2}{*}{ Kv } & \multicolumn{3}{|c|}{ Danmark } & \multicolumn{3}{|c|}{ Sverige } \\
\hline & & & & Totalt & Män & Kv & Totalt & Män & Kv \\
\hline $\begin{array}{l}\text { Alla födelse- } \\
\text { regioner }\end{array}$ & 4261 & 2656 & 1605 & 3132 & 1893 & 1239 & 1129 & 763 & 366 \\
\hline Danmark & 2187 & 1735 & 452 & 1448 & 1198 & 250 & 739 & 537 & 202 \\
\hline Finland & 14 & 8 & 6 & 4 & 4 & 0 & 10 & 4 & 6 \\
\hline Norge & 1441 & 561 & 880 & 1428 & 553 & 875 & 13 & 8 & 5 \\
\hline Sverige & 301 & 154 & 147 & 46 & 23 & 23 & 255 & 131 & 124 \\
\hline Island & 16 & 12 & 4 & 12 & 10 & 2 & 4 & 2 & 2 \\
\hline Övriga EU27 & 130 & 84 & 46 & 76 & 45 & 31 & 54 & 39 & 15 \\
\hline
\end{tabular}


Tabell 2aa. Förändring av antal danska arbetspendlare 2009 jämfört med 2008 efter födelseregion och kön

\begin{tabular}{|c|c|c|c|c|c|c|c|c|c|}
\hline \multicolumn{4}{|c|}{$\begin{array}{l}\text { Procentuell förändring av danska ar- } \\
\text { betspendlare }\end{array}$} & \multicolumn{6}{|c|}{ Därav till } \\
\hline \multirow[b]{2}{*}{ Födelseregion } & \multirow[b]{2}{*}{ Totalt } & \multirow[b]{2}{*}{ Män } & \multirow[b]{2}{*}{ Kv } & \multicolumn{3}{|c|}{ Norge } & \multicolumn{3}{|c|}{ Sverige } \\
\hline & & & & Totalt & Män & Kv & Totalt & Män & Kv \\
\hline $\begin{array}{l}\text { Alla födelse- } \\
\text { regioner }\end{array}$ & $-2,9$ & $-5,5$ & 1,9 & 1,0 & $-1,4$ & 4,9 & $-12,2$ & $-14,5$ & $-7,1$ \\
\hline Danmark & $-6,9$ & $-7,2$ & $-6,0$ & $-4,5$ & $-3,6$ & $-8,8$ & $-11,3$ & $-14,2$ & $-2,4$ \\
\hline Finland & 7,7 & 14,3 & 0,0 & $-20,0$ & $-20,0$ & 0,0 & 25,0 & 100,0 & 0,0 \\
\hline Norge & 8,5 & 7,7 & 9,0 & 8,8 & 8,4 & 9,1 & $-18,8$ & $-27,3$ & 0,0 \\
\hline Sverige & $-10,9$ & $-15,8$ & $-5,2$ & $-8,0$ & $-14,8$ & 0,0 & $-11,5$ & $-16,0$ & $-6,1$ \\
\hline Island & 23,1 & 50,0 & $-20,0$ & 71,4 & 66,7 & 100,0 & $-33,3$ & 0,0 & $-50,0$ \\
\hline Övriga EU27 & $-19,3$ & $-26,3$ & $-2,1$ & $-18,3$ & $-29,7$ & 6,9 & $-20,6$ & $-22,0$ & $-16,7$ \\
\hline Övriga Europa & 13,0 & 28,6 & $-11,1$ & $-6,7$ & $-11,1$ & 0,0 & 50,0 & 100,0 & $-33,3$ \\
\hline Övriga Världen & $-9,3$ & $-12,5$ & $-4,6$ & 2,0 & $-7,1$ & 13,0 & $-28,8$ & $-20,0$ & $-47,4$ \\
\hline
\end{tabular}

Tabell 2b. Antal norska arbetspendlare efter födelseregion och kön 2009

\begin{tabular}{|c|c|c|c|c|c|c|c|c|c|}
\hline \multicolumn{4}{|c|}{ Totalt antal norska arbetspendlare } & \multicolumn{6}{|l|}{ Därav till } \\
\hline \multirow[b]{2}{*}{ Födelseregion } & \multirow[b]{2}{*}{ Totalt } & \multirow[b]{2}{*}{ Män } & \multirow[b]{2}{*}{ Kv } & \multicolumn{2}{|l|}{ Danmark } & \multicolumn{3}{|c|}{ Sverige } & \multirow[b]{2}{*}{ Kv } \\
\hline & & & & Totalt & Män & Kv & Totalt & Män & \\
\hline $\begin{array}{l}\text { Alla födelse- } \\
\text { regioner }\end{array}$ & 1158 & 755 & 403 & 325 & 232 & 93 & 833 & 523 & 310 \\
\hline Danmark & 119 & 82 & 37 & 114 & 79 & 35 & 5 & 3 & 2 \\
\hline Finland & 9 & 8 & 1 & 0 & 0 & 0 & 9 & 8 & 1 \\
\hline Norge & 692 & 429 & 263 & 152 & 108 & 44 & 540 & 321 & 219 \\
\hline Sverige & 216 & 149 & 67 & 15 & 9 & 6 & 201 & 140 & 61 \\
\hline Island & 0 & 0 & 0 & 0 & 0 & 0 & 0 & 0 & 0 \\
\hline Övriga EU27 & 37 & 30 & 7 & 24 & 20 & 4 & 13 & 10 & 3 \\
\hline Övriga Europa & 30 & 18 & 12 & 4 & 3 & 1 & 26 & 15 & 11 \\
\hline Övriga Världen & 55 & 39 & 16 & 16 & 13 & 3 & 39 & 26 & 13 \\
\hline
\end{tabular}

Tabell 2bb. Förändring av antal norska arbetspendlare 2009 jämfört med 2008 efter födelseregion och kön

\begin{tabular}{|c|c|c|c|c|c|c|c|c|c|}
\hline \multicolumn{4}{|c|}{$\begin{array}{l}\text { Procentuell förändring av } \\
\text { norska arbetspendlare }\end{array}$} & \multicolumn{6}{|c|}{ Därav till } \\
\hline \multirow[b]{2}{*}{ Födelseregion } & \multirow[b]{2}{*}{ Totalt } & \multirow[b]{2}{*}{ Män } & \multirow[b]{2}{*}{ Kv } & \multicolumn{3}{|c|}{ Danmark } & \multicolumn{3}{|c|}{ Sverige } \\
\hline & & & & Totalt & Män & Kv & Totalt & Män & $\mathrm{Kv}$ \\
\hline $\begin{array}{l}\text { Alla födelse- } \\
\text { regioner }\end{array}$ & $-20,5$ & $-15,5$ & $-28,5$ & $-17,5$ & 1,8 & $-44,0$ & $-21,6$ & $-21,4$ & $-22,1$ \\
\hline Danmark & $-37,4$ & $-26,8$ & $-52,6$ & $-37,4$ & $-26,2$ & $-53,3$ & $-37,5$ & $-40,0$ & $-33,3$ \\
\hline Finland & $-35,7$ & $-38,5$ & 0,0 & $-100,0$ & $-100,0$ & 0,0 & $-30,8$ & $-33,3$ & 0,0 \\
\hline Norge & $-13,0$ & $-6,7$ & $-21,5$ & $-2,6$ & 42,1 & $-45,0$ & $-15,5$ & $-16,4$ & $-14,1$ \\
\hline Sverige & $-31,2$ & $-27,7$ & $-38,0$ & 15,4 & $-18,2$ & 200,0 & $-33,2$ & $-28,2$ & $-42,5$ \\
\hline Island & 0,0 & 0,0 & 0,0 & 0,0 & 0,0 & 0,0 & 0,0 & 0,0 & 0,0 \\
\hline Övriga EU27 & $-36,2$ & $-40,0$ & $-12,5$ & $-7,7$ & $-20,0$ & 300,0 & $-59,4$ & $-60,0$ & $-57,1$ \\
\hline Övriga Europa & $-26,8$ & $-21,7$ & $-33,3$ & 33,3 & 50,0 & 0,0 & $-31,6$ & $-28,6$ & $-35,3$ \\
\hline Övriga Världen & 22,2 & 34,5 & 0,0 & 23,1 & 116,7 & $-57,1$ & 21,9 & 13,0 & 44,4 \\
\hline
\end{tabular}


Tabell 2c. Antal svenska arbetspendlare efter födelseregion och kön 2009

\begin{tabular}{|c|c|c|c|c|c|c|c|c|c|}
\hline \multicolumn{4}{|c|}{ Totalt antal svenska arbetspendlare } & \multicolumn{6}{|c|}{ Därav till } \\
\hline \multirow[b]{2}{*}{ Födelseregion } & \multirow[b]{2}{*}{ Totalt } & \multirow[b]{2}{*}{ Män } & \multirow[b]{2}{*}{ Kv } & \multicolumn{3}{|c|}{ Danmark } & \multicolumn{3}{|c|}{ Norge } \\
\hline & & & & Totalt & Män & Kv & Totalt & Män & Kv \\
\hline $\begin{array}{l}\text { Alla födelse- } \\
\text { regioner }\end{array}$ & 48330 & 31079 & 17251 & 20189 & 11949 & 8240 & 28141 & 19130 & 9011 \\
\hline Danmark & 7378 & 4789 & 2589 & 7227 & 4668 & 2559 & 151 & 121 & 30 \\
\hline Finland & 552 & 381 & 171 & 147 & 68 & 79 & 405 & 313 & 92 \\
\hline Norge & 2961 & 1931 & 1030 & 164 & 103 & 61 & 2797 & 1828 & 969 \\
\hline Sverige & 31111 & 19944 & 11167 & 8468 & 4540 & 3928 & 22643 & 15404 & 7239 \\
\hline Island & 76 & 47 & 29 & 44 & 25 & 19 & 32 & 22 & 10 \\
\hline Övriga EU27 & 1430 & 886 & 544 & 880 & 499 & 381 & 550 & 387 & 163 \\
\hline Övriga Europa & 1395 & 871 & 524 & 976 & 588 & 388 & 419 & 283 & 136 \\
\hline Övriga Världen & 3427 & 2230 & 1197 & 2283 & 1458 & 825 & 1144 & 772 & 372 \\
\hline
\end{tabular}

Tabell 2cc. Förändring av antal svenska arbetspendlare 2009 jämfört med 2008 efter födelseregion och kön

\begin{tabular}{|c|c|c|c|c|c|c|c|c|c|}
\hline \multicolumn{4}{|c|}{$\begin{array}{l}\text { Procentuell förändring av svenska ar- } \\
\text { betspendlare }\end{array}$} & \multicolumn{6}{|c|}{ Därav till } \\
\hline \multirow[b]{2}{*}{ Födelseregion } & \multirow[b]{2}{*}{ Totalt } & \multirow[b]{2}{*}{ Män } & \multirow[b]{2}{*}{ Kv } & \multicolumn{3}{|c|}{ Danmark } & \multicolumn{3}{|c|}{ Norge } \\
\hline & & & & Totalt & Män & Kv & Totalt & Män & Kv \\
\hline $\begin{array}{l}\text { Alla födelse- } \\
\text { regioner }\end{array}$ & 2,8 & 2,0 & 4,1 & $-3,0$ & $-3,5$ & $-2,3$ & 7,3 & 10,8 & 5,8 \\
\hline Danmark & $-4,3$ & $-4,2$ & $-4,4$ & $-4,5$ & $-4,4$ & $-4,7$ & 5,6 & 20,0 & 2,5 \\
\hline Finland & 5,1 & 0,5 & 17,1 & 6,5 & 9,7 & 3,9 & 4,7 & 31,4 & $-1,3$ \\
\hline Norge & 1,1 & 2,4 & $-1,3$ & $-8,9$ & $-6,4$ & $-12,9$ & 1,7 & $-0,5$ & 2,9 \\
\hline Sverige & 4,9 & 3,8 & 7,0 & $-1,3$ & $-1,8$ & $-0,6$ & 7,5 & 11,6 & 5,6 \\
\hline Island & 13,4 & 17,5 & 7,4 & $-4,3$ & 4,2 & $-13,6$ & 52,4 & 100,0 & 37,5 \\
\hline Övriga EU27 & 7,1 & 3,1 & 14,3 & 2,9 & $-1,2$ & 8,9 & 14,6 & 29,4 & 9,3 \\
\hline Övriga Europa & $-0,2$ & 0,7 & $-1,7$ & $-6,8$ & $-5,0$ & $-9,3$ & 19,4 & 29,5 & 15,0 \\
\hline Övriga Världen & 0,2 & 0,1 & 0,3 & $-4,9$ & $-5,9$ & $-3,2$ & 12,2 & 8,8 & 13,9 \\
\hline
\end{tabular}

Tabell 3a. Antal danska arbetspendlare efter utbildningsnivå och kön 2009

\begin{tabular}{|c|c|c|c|c|c|c|c|c|c|}
\hline \multicolumn{4}{|c|}{ Totalt antal danska arbetspendlare } & \multicolumn{6}{|c|}{ Därav till } \\
\hline \multirow[b]{2}{*}{ Utbildningsnivå } & \multirow[b]{2}{*}{ Totalt } & \multirow[b]{2}{*}{ Män } & \multirow[b]{2}{*}{ Kv } & \multicolumn{3}{|c|}{ Norge } & \multicolumn{3}{|c|}{ Sverige } \\
\hline & & & & Totalt & Män & Kv & Totalt & Män & Kv \\
\hline Alla utbildningsnivåer & 4261 & 2656 & 1605 & 3132 & 1893 & 1239 & 1129 & 763 & 366 \\
\hline $\begin{array}{l}\text { Förgymnasial utbildning } \\
\text { (ISCED 1+2) }\end{array}$ & 557 & 364 & 193 & 441 & 279 & 162 & 116 & 85 & 31 \\
\hline $\begin{array}{l}\text { Gymnasial utbildning, } \\
\text { högst } 3 \text { år (ISCED 3+4) }\end{array}$ & 1731 & 1105 & 626 & 1429 & 883 & 546 & 302 & 222 & 80 \\
\hline $\begin{array}{l}\text { Eftergymnasial utbildning } \\
\text { inkl. 4-årig gymnasial } \\
\text { (ISCED 5-7) }\end{array}$ & 1801 & 1089 & 712 & 1120 & 652 & 468 & 681 & 437 & 244 \\
\hline Okänd utbildningsnivå & 172 & 98 & 74 & 142 & 79 & 63 & 30 & 19 & 11 \\
\hline
\end{tabular}


Tabell 3aa. Förändring av antal danska arbetspendlare 2009 jämfört med 2008 efter utbildningsnivå och kön

\begin{tabular}{|c|c|c|c|c|c|c|c|c|c|}
\hline \multicolumn{4}{|c|}{ Procentuell förändring av danska arbetspendlare } & \multicolumn{6}{|c|}{ Därav till } \\
\hline \multirow[b]{2}{*}{ Utbildningsnivå } & \multirow[b]{2}{*}{ Totalt } & \multirow[b]{2}{*}{ Män } & \multirow[b]{2}{*}{ Kv } & \multicolumn{3}{|c|}{ Norge } & \multicolumn{3}{|c|}{ Sverige } \\
\hline & & & & Totalt & Män & Kv & Totalt & Män & Kv \\
\hline Alla utbildningsnivåer & $-2,9$ & $-5,5$ & 1,9 & 1,0 & $-1,4$ & 4,9 & $-12,2$ & $-14,5$ & $-7,1$ \\
\hline $\begin{array}{l}\text { Förgymnasial utbildning } \\
\text { (ISCED 1+2) }\end{array}$ & 36,9 & 11,3 & 141,3 & 58,6 & 23,5 & 211,5 & $-10,1$ & $-15,8$ & 10,7 \\
\hline $\begin{array}{l}\text { Gymnasial utbildning, } \\
\text { högst } 3 \text { år (ISCED 3+4) }\end{array}$ & 49,1 & 17,7 & 182,0 & 72,0 & 26,9 & 304,4 & $-8,5$ & $-8,6$ & $-8,0$ \\
\hline $\begin{array}{l}\text { Eftergymnasial utbildning } \\
\text { inkl. 4-årig gymnasial } \\
\text { (ISCED 5-7) }\end{array}$ & 20,2 & 8,0 & 45,3 & 56,6 & 32,8 & 108,9 & $-13,0$ & $-15,5$ & $-8,3$ \\
\hline Okänd utbildningsnivå & $-87,0$ & $-81,8$ & $-90,5$ & $-88,9$ & $-84,4$ & $-91,8$ & $-31,8$ & $-38,7$ & $-15,4$ \\
\hline
\end{tabular}

Tabell 3b. Antal norska arbetspendlare efter utbildningsnivå och kön 2009

\begin{tabular}{|c|c|c|c|c|c|c|c|c|c|}
\hline \multicolumn{4}{|c|}{ Totalt antal norska arbetspendlare } & \multicolumn{6}{|c|}{ Därav till } \\
\hline \multirow[b]{2}{*}{ Utbildningsnivå } & \multirow[b]{2}{*}{ Totalt } & \multirow[b]{2}{*}{ Män } & \multirow[b]{2}{*}{ Kv } & \multicolumn{3}{|c|}{ Danmark } & \multicolumn{3}{|c|}{ Sverige } \\
\hline & & & & Totalt & Män & Kv & Totalt & Män & Kv \\
\hline Alla utbildningsnivåer & 1158 & 755 & 403 & 325 & 232 & 93 & 833 & 523 & 310 \\
\hline $\begin{array}{l}\text { Förgymnasial utbildning } \\
\text { (ISCED 1+2) }\end{array}$ & 222 & 137 & 85 & 35 & 28 & 7 & 187 & 109 & 78 \\
\hline $\begin{array}{l}\text { Gymnasial utbildning, } \\
\text { högst } 3 \text { år (ISCED 3+4) }\end{array}$ & 400 & 249 & 151 & 93 & 71 & 22 & 307 & 178 & 129 \\
\hline $\begin{array}{l}\text { Eftergymnasial utbildning } \\
\text { inkl. 4-årig gymnasial } \\
\text { (ISCED 5-7) }\end{array}$ & 473 & 322 & 151 & 144 & 94 & 50 & 329 & 228 & 101 \\
\hline Okänd utbildningsnivå & 63 & 47 & 16 & 53 & 39 & 14 & 10 & 8 & 2 \\
\hline
\end{tabular}


Tabell 3bb. Förändring av antal norska arbetspendlare 2009 jämfört med 2008 efter utbildningsnivå och kön

\begin{tabular}{|c|c|c|c|c|c|c|c|c|c|}
\hline \multicolumn{4}{|c|}{ Procentuell förändring avnorska arbetspendlare } & \multicolumn{6}{|c|}{ Därav till } \\
\hline \multirow[b]{2}{*}{ Utbildningsnivå } & \multirow[b]{2}{*}{ Totalt } & \multirow[b]{2}{*}{ Män } & \multirow[b]{2}{*}{ Kv } & \multicolumn{3}{|c|}{ Danmark } & \multicolumn{3}{|c|}{ Sverige } \\
\hline & & & & Totalt & Män & Kv & Totalt & Män & Kv \\
\hline Alla utbildningsnivåer & $-20,5$ & $-15,5$ & $-28,5$ & $-17,5$ & 1,8 & $-44,0$ & $-21,6$ & $-21,4$ & $-22,1$ \\
\hline $\begin{array}{l}\text { Förgymnasial utbildning } \\
\text { (ISCED 1+2) }\end{array}$ & $-9,4$ & 3,8 & $-24,8$ & 250,0 & 250,0 & 250,0 & $-20,4$ & $-12,1$ & $-29,7$ \\
\hline $\begin{array}{l}\text { Gymnasial utbildning, } \\
\text { högst } 3 \text { år (ISCED 3+4) }\end{array}$ & $-22,9$ & $-20,7$ & $-26,3$ & $-31,1$ & $-15,5$ & $-56,9$ & $-20,1$ & $-22,6$ & $-16,2$ \\
\hline $\begin{array}{l}\text { Eftergymnasial utbildning } \\
\text { inkl. 4-årig gymnasial } \\
\text { (ISCED 5-7) }\end{array}$ & $-18,3$ & $-13,7$ & $-26,7$ & $-8,9$ & 16,0 & $-35,1$ & $-21,9$ & $-21,9$ & $-21,7$ \\
\hline Okänd utbildningsnivå & $-44,7$ & $-36,5$ & $-60,0$ & $-41,8$ & $-29,1$ & $-61,1$ & $-56,5$ & $-57,9$ & $-50,0$ \\
\hline
\end{tabular}

Tabell 3c. Antal svenska arbetspendlare efter utbildningsnivå och kön 2009

\begin{tabular}{|c|c|c|c|c|c|c|c|c|c|}
\hline \multicolumn{4}{|c|}{ Totalt antal svenska arbetspendlare } & \multicolumn{6}{|c|}{ Därav till } \\
\hline \multirow[b]{2}{*}{ Utbildningsnivå } & \multirow[b]{2}{*}{ Totalt } & \multirow[b]{2}{*}{ Män } & \multirow[b]{2}{*}{ Kv } & \multicolumn{3}{|c|}{ Danmark } & \multicolumn{3}{|c|}{ Norge } \\
\hline & & & & Totalt & Män & Kv & Totalt & Män & Kv \\
\hline $\begin{array}{l}\text { Alla utbildnings- } \\
\text { nivåer }\end{array}$ & 48330 & 31079 & 17251 & 20189 & 11949 & 8240 & 28141 & 19130 & 9011 \\
\hline $\begin{array}{l}\text { Förgymnasial } \\
\text { utbildning } \\
\text { (ISCED } 1+2 \text { ) }\end{array}$ & 5572 & 4193 & 1379 & 2480 & 1643 & 837 & 3092 & 2550 & 542 \\
\hline $\begin{array}{l}\text { Gymnasial } \\
\text { utbildning, högst } \\
3 \text { år (ISCED 3+4) }\end{array}$ & 28480 & 18515 & 9965 & 9235 & 5212 & 4023 & 19245 & 13303 & 5942 \\
\hline $\begin{array}{l}\text { Eftergymnasial } \\
\text { utbildning inkl. 4- } \\
\text { årig gymnasial } \\
\text { (ISCED 5-7) }\end{array}$ & 13721 & 7969 & 5752 & 8091 & 4827 & 3264 & 5630 & 3142 & 2488 \\
\hline $\begin{array}{l}\text { Okänd utbild- } \\
\text { ningsnivå }\end{array}$ & 557 & 402 & 155 & 383 & 267 & 116 & 174 & 135 & 39 \\
\hline
\end{tabular}

Tabell 3cc. Förändring av antal svenska arbetspendlare 2009 jämfört med 2008 efter och kön

\begin{tabular}{|c|c|c|c|c|c|c|c|c|c|}
\hline \multicolumn{4}{|c|}{ Procentuell förändring av svenska arbetspendlare } & \multicolumn{6}{|c|}{ Därav till } \\
\hline \multirow[b]{2}{*}{ Utbildningsnivå } & \multirow[b]{2}{*}{ Totalt } & \multirow[b]{2}{*}{ Män } & \multirow[b]{2}{*}{ Kv } & \multicolumn{3}{|c|}{ Danmark } & \multicolumn{3}{|c|}{ Norge } \\
\hline & & & & Totalt & Män & Kv & Totalt & Män & Kv \\
\hline Alla utbildningsnivåer & 2,8 & 2,0 & 4,1 & $-3,0$ & $-3,5$ & $-2,3$ & 7,3 & 5,8 & 10,8 \\
\hline $\begin{array}{l}\text { Förgymnasial utbildning } \\
\text { (ISCED 1+2) }\end{array}$ & $-5,5$ & $-3,4$ & $-11,2$ & $-14,1$ & $-13,0$ & $-16,1$ & 2,8 & 3,9 & $-2,3$ \\
\hline $\begin{array}{l}\text { Gymnasial utbildning, } \\
\text { högst } 3 \text { år (ISCED 3+4) }\end{array}$ & 2,6 & 2,2 & 3,5 & $-4,6$ & $-5,0$ & $-4,1$ & 6,5 & 5,3 & 9,3 \\
\hline $\begin{array}{l}\text { Eftergymnasial utbild- } \\
\text { ning inkl. 4-årig gymn- } \\
\text { asial (ISCED 5-7) }\end{array}$ & 6,8 & 4,6 & 9,9 & 2,7 & 1,5 & 4,5 & 13,3 & 9,9 & 17,9 \\
\hline Okänd utbildningsnivå & 4,3 & 4,7 & 3,3 & 6,1 & 9,9 & $-1,7$ & 0,6 & $-4,3$ & 21,9 \\
\hline
\end{tabular}


Tabell 4a. Antal danska arbetspendlare efter sektor och kön 2009

\begin{tabular}{|c|c|c|c|c|c|c|c|c|c|}
\hline \multicolumn{4}{|c|}{ Totalt antal danska arbetspendlare } & \multicolumn{6}{|c|}{ Därav till } \\
\hline \multirow[b]{2}{*}{ Sektor } & \multirow[b]{2}{*}{ Totalt } & \multirow[b]{2}{*}{ Män } & \multirow[b]{2}{*}{ Kv } & \multicolumn{3}{|c|}{ Norge } & \multicolumn{3}{|c|}{ Sverige } \\
\hline & & & & Totalt & Män & Kv & Totalt & Män & Kv \\
\hline Alla sektorer & 4261 & 2656 & 1605 & 3132 & 1893 & 1239 & 1129 & 763 & 366 \\
\hline $\begin{array}{l}\text { Offentlig förvaltning och } \\
\text { service }\end{array}$ & 756 & 334 & 422 & 501 & 197 & 304 & 255 & 137 & 118 \\
\hline $\begin{array}{l}\text { Offentligt ägda företag } \\
\text { och organisationer }\end{array}$ & 134 & 84 & 50 & 87 & 65 & 22 & 47 & 19 & 28 \\
\hline $\begin{array}{l}\text { Näringslivet exkl. off. } \\
\text { bolag o organisationer }\end{array}$ & 3371 & 2238 & 1133 & 2544 & 1631 & 913 & 827 & 607 & 220 \\
\hline Okänd sektor & 0 & 0 & 0 & 0 & 0 & 0 & 0 & 0 & 0 \\
\hline
\end{tabular}

Tabell 4aa. Förändring av antal danska arbetspendlare 2009 jämfört med 2008 efter sektor och kön

\begin{tabular}{|c|c|c|c|c|c|c|c|c|c|}
\hline \multicolumn{4}{|c|}{ Procentuell förändring av danska arbetspendlare } & \multicolumn{6}{|c|}{ Därav till } \\
\hline \multirow[b]{2}{*}{ Sektor } & \multirow[b]{2}{*}{ Totalt } & \multirow[b]{2}{*}{ Män } & \multirow[b]{2}{*}{ Kv } & \multicolumn{3}{|c|}{ Norge } & \multicolumn{3}{|c|}{ Sverige } \\
\hline & & & & Totalt & Män & Kv & Totalt & Män & Kv \\
\hline Alla sektorer & $-2,9$ & $-5,5$ & 1,9 & 1,0 & $-1,4$ & 4,9 & $-12,2$ & $-14,5$ & $-7,1$ \\
\hline $\begin{array}{l}\text { Offentlig förvaltning och } \\
\text { service }\end{array}$ & $-8,4$ & $-17,9$ & 1,0 & $-5,1$ & $-12,4$ & 0,3 & $-14,1$ & $-24,7$ & 2,6 \\
\hline $\begin{array}{l}\text { Offentligt ägda företag } \\
\text { och organisationer }\end{array}$ & $-7,6$ & $-2,3$ & $-15,3$ & $-5,4$ & 4,8 & $-26,7$ & $-11,3$ & $-20,8$ & $-3,4$ \\
\hline $\begin{array}{l}\text { Näringslivet exkl. off. } \\
\text { bolag o organisationer }\end{array}$ & $-1,3$ & $-3,5$ & 3,2 & 2,5 & $-0,1$ & 7,7 & $-11,6$ & $-11,5$ & $-12,0$ \\
\hline Okänd sektor & .. & .. & .. & .. & .. & .. & .. & .. & .. \\
\hline
\end{tabular}

Tabell 4b. Antal norska arbetspendlare efter sektor och kön 2009

\begin{tabular}{|c|c|c|c|c|c|c|c|c|c|}
\hline \multicolumn{4}{|c|}{ Totalt antal norska arbetspendlare } & \multicolumn{6}{|c|}{ Därav till } \\
\hline \multirow[b]{2}{*}{ Sektor } & \multirow[b]{2}{*}{ Totalt } & \multirow[b]{2}{*}{ Män } & \multirow[b]{2}{*}{ Kv } & \multicolumn{3}{|c|}{ Sverige } & \multicolumn{3}{|c|}{ Danmark } \\
\hline & & & & Totalt & Män & Kv & Totalt & Män & Kv \\
\hline Alla sektorer & 1158 & 755 & 403 & 833 & 523 & 310 & 325 & 232 & 93 \\
\hline $\begin{array}{l}\text { Offentlig förvaltning och } \\
\text { service }\end{array}$ & 237 & 133 & 104 & 146 & 84 & 62 & 91 & 49 & 42 \\
\hline $\begin{array}{l}\text { Offentligt ägda företag } \\
\text { och organisationer }\end{array}$ & 68 & 52 & 16 & 25 & 16 & 9 & 43 & 36 & 7 \\
\hline $\begin{array}{l}\text { Näringslivet exkl. off. } \\
\text { bolag o organisationer }\end{array}$ & 852 & 569 & 283 & 662 & 423 & 239 & 190 & 146 & 44 \\
\hline Okänd sektor & 1 & 1 & 0 & 0 & 0 & 0 & 1 & 1 & 0 \\
\hline
\end{tabular}


Tabell 4bb. Förändring av antal norska arbetspendlare 2009 jämfört med 2008 efter sektor och kön

\begin{tabular}{|c|c|c|c|c|c|c|c|c|c|}
\hline \multicolumn{4}{|c|}{ Procentuell förändring av norska arbetspendlare } & \multicolumn{6}{|c|}{ Därav till } \\
\hline \multirow[b]{2}{*}{ Sektor } & \multirow[b]{2}{*}{ Totalt } & \multirow[b]{2}{*}{ Män } & \multirow[b]{2}{*}{ Kv } & \multicolumn{3}{|c|}{ Sverige } & \multicolumn{3}{|c|}{ Danmark } \\
\hline & & & & Totalt & Män & Kv & Totalt & Män & Kv \\
\hline Alla sektorer & $-20,5$ & $-15,5$ & $-28,5$ & $-21,6$ & $-21,4$ & $-22,1$ & $-17,5$ & 1,8 & $-44,0$ \\
\hline $\begin{array}{l}\text { Offentlig förvaltning och } \\
\text { service }\end{array}$ & $-15,4$ & 9,0 & $-34,2$ & $-8,2$ & 1,2 & $-18,4$ & $-24,8$ & 25,6 & $-48,8$ \\
\hline $\begin{array}{l}\text { Offentligt ägda företag } \\
\text { och organisationer }\end{array}$ & $-11,7$ & $-10,3$ & $-15,8$ & $-32,4$ & $-33,3$ & $-30,8$ & 7,5 & 5,9 & 16,7 \\
\hline $\begin{array}{l}\text { Näringslivet exkl. off. } \\
\text { bolag o organisationer }\end{array}$ & $-22,5$ & $-20,2$ & $-26,9$ & $-23,6$ & $-24,2$ & $-22,7$ & $-18,5$ & $-5,8$ & $-43,6$ \\
\hline Okänd sektor & .. & .. & .. & .. & .. & .. & .. & .. & .. \\
\hline
\end{tabular}

Tabell 4c. Antal svenska arbetspendlare efter sektor och kön 2009

\begin{tabular}{|c|c|c|c|c|c|c|c|c|c|}
\hline \multicolumn{4}{|c|}{ Totalt antal svenska arbetspendlare } & \multicolumn{6}{|c|}{ Därav till } \\
\hline \multirow[b]{2}{*}{ Sektor } & \multirow[b]{2}{*}{ Totalt } & \multirow[b]{2}{*}{ Män } & \multirow[b]{2}{*}{ Kv } & \multicolumn{3}{|c|}{ Norge } & \multicolumn{3}{|c|}{ Danmark } \\
\hline & & & & Totalt & Män & Kv & Totalt & Män & Kv \\
\hline Alla sektorer & 48330 & 31079 & 17251 & 28141 & 19130 & 9011 & 20189 & 11949 & 8240 \\
\hline $\begin{array}{l}\text { Offentlig förvalt- } \\
\text { ning och service }\end{array}$ & 6388 & 2428 & 3960 & 2354 & 868 & 1486 & 4034 & 1560 & 2474 \\
\hline $\begin{array}{l}\text { Offentligt ägda } \\
\text { företag och } \\
\text { organisationer }\end{array}$ & 2158 & 1389 & 769 & 663 & 514 & 149 & 1495 & 875 & 620 \\
\hline $\begin{array}{l}\text { Näringslivet } \\
\text { exkl. off. bolag o } \\
\text { organisationer }\end{array}$ & 39783 & 27261 & 12522 & 25124 & 17748 & 7376 & 14659 & 9513 & 5146 \\
\hline Okänd sektor & 1 & 1 & 0 & 0 & 0 & 0 & 1 & 1 & 0 \\
\hline
\end{tabular}

Tabell 4cc. Förändring av antal svenska arbetspendlare 2009 jämfört med 2008 efter sektor och kön

\begin{tabular}{|c|c|c|c|c|c|c|c|c|c|}
\hline \multicolumn{4}{|c|}{ Procentuell förändring av svenska arbetspendlare } & \multicolumn{6}{|c|}{ Därav till } \\
\hline \multirow[b]{2}{*}{ Sektor } & \multirow[b]{2}{*}{ Totalt } & \multirow[b]{2}{*}{ Män } & \multirow[b]{2}{*}{ Kv } & \multicolumn{3}{|c|}{ Norge } & \multicolumn{3}{|c|}{ Danmark } \\
\hline & & & & Totalt & Män & Kv & Totalt & Män & Kv \\
\hline Alla sektorer & 2,8 & 2,0 & 4,0 & 7,3 & 5,8 & 10,8 & $-3,0$ & $-3,5$ & $-2,3$ \\
\hline $\begin{array}{l}\text { Offentlig förvalt- } \\
\text { ning och service }\end{array}$ & 15,8 & 15,5 & 13,8 & 20,9 & 17,1 & 23,2 & 13,0 & 14,5 & 12,1 \\
\hline $\begin{array}{l}\text { Offentligt ägda } \\
\text { företag och } \\
\text { organisationer }\end{array}$ & $-2,0$ & 1,4 & $-8,2$ & 15,3 & 17,9 & 7,2 & $-8,1$ & $-6,3$ & $-10,5$ \\
\hline $\begin{array}{l}\text { Näringslivet exkl. } \\
\text { off. bolag o } \\
\text { organisationer }\end{array}$ & 1,2 & 1,0 & 1,6 & 6,0 & 5,0 & 8,6 & $-6,1$ & $-5,6$ & $-7,0$ \\
\hline Okänd sektor & 0,0 & 0,0 & .. & .. & .. & .. & 0,0 & 0,0 & .. \\
\hline
\end{tabular}


Tabell 5a. Antal danska arbetspendlare efter näringsgren och kön 2009

\begin{tabular}{|c|c|c|c|c|c|c|c|c|c|}
\hline \multirow{3}{*}{$\begin{array}{l}\text { Totalt antal danska arbetspendlare } \\
\text { Näringsgren1 }\end{array}$} & \multirow[b]{3}{*}{ Totalt } & \multirow[b]{3}{*}{ Män } & \multirow[b]{3}{*}{ Kv } & \multicolumn{6}{|c|}{ Därav till } \\
\hline & & & & \multicolumn{3}{|c|}{ Norge } & \multicolumn{3}{|c|}{ Sverige } \\
\hline & & & & Totalt & Män & Kv & Totalt & Män & Kv \\
\hline \multirow[t]{2}{*}{ Alla näringsgrenar } & 4261 & 2 & 1 & 3132 & 1 & 1 & 1129 & 763 & 366 \\
\hline & & 656 & 605 & & 893 & 239 & & & \\
\hline A-Jordbruk, jakt, fiske & 59 & 41 & 18 & 49 & 32 & 17 & 10 & 9 & 1 \\
\hline B-Utvinning av mineral & 333 & 324 & 9 & 333 & 324 & 9 & 0 & 0 & 0 \\
\hline C-Tillverkning & 285 & 242 & 43 & 198 & 170 & 28 & 87 & 72 & 15 \\
\hline $\begin{array}{l}\text { D-Försörjning av el, gas, värme } \\
\text { och kyla }\end{array}$ & 5 & 3 & 2 & 2 & 0 & 2 & 3 & 3 & 0 \\
\hline $\begin{array}{l}\text { E-Vattenförsörjning; avloppsre- } \\
\text { ning, avfallshantering och } \\
\text { sanering }\end{array}$ & 33 & 32 & 1 & 30 & 29 & 1 & 3 & 3 & 0 \\
\hline F-Byggverksamhet & 303 & 290 & 13 & 292 & 282 & 10 & 11 & 8 & 3 \\
\hline $\begin{array}{l}\text { G-Handel; reparation av motor- } \\
\text { fordon och motorcyklar }\end{array}$ & 566 & 278 & 288 & 399 & 146 & 253 & 167 & 132 & 35 \\
\hline $\mathrm{H}$-Transport och magasinering & 330 & 263 & 67 & 174 & 133 & 41 & 156 & 130 & 26 \\
\hline $\begin{array}{l}\text { I-Hotell- och restaurangverk- } \\
\text { samhet }\end{array}$ & 268 & 105 & 163 & 249 & 93 & 156 & 19 & 12 & 7 \\
\hline $\begin{array}{l}\text { J-Informations- och kommunikat- } \\
\text { ionsverksamhet }\end{array}$ & 133 & 84 & 49 & 72 & 45 & 27 & 61 & 39 & 22 \\
\hline $\begin{array}{l}\text { K-Finans- och försäkringsverk- } \\
\text { samhet }\end{array}$ & 68 & 39 & 29 & 25 & 9 & 16 & 43 & 30 & 13 \\
\hline L-Fastighetsverksamhet & 25 & 14 & 11 & 22 & 11 & 11 & 3 & 3 & 0 \\
\hline $\begin{array}{l}\text { M-Verksamhet inom juridik, } \\
\text { ekonomi, vetenskap och teknik }\end{array}$ & 332 & 189 & 143 & 153 & 80 & 73 & 179 & 109 & 70 \\
\hline $\begin{array}{l}\mathrm{N} \text {-Uthyrning, fastighetsservice, } \\
\text { resetjänster och andra stödtjäns- } \\
\text { ter }\end{array}$ & 369 & 262 & 107 & 339 & 238 & 101 & 30 & 24 & 6 \\
\hline $\begin{array}{l}\text { O-Offentlig förvaltning och } \\
\text { försvar; obligatorisk socialförsäk- } \\
\text { ring }\end{array}$ & 273 & 115 & 158 & 235 & 98 & 137 & 38 & 17 & 21 \\
\hline P-Utbildning & 186 & 92 & 94 & 67 & 31 & 36 & 119 & 61 & 58 \\
\hline $\begin{array}{l}\text { Q-Vård och omsorg; sociala } \\
\text { tjänster }\end{array}$ & 433 & 174 & 259 & 303 & 97 & 206 & 130 & 77 & 53 \\
\hline R-Kultur, nöje och fritid & 160 & 72 & 88 & 105 & 46 & 59 & 55 & 26 & 29 \\
\hline S-Annan serviceverksamhet & 64 & 24 & 40 & 52 & 17 & 35 & 12 & 7 & 5 \\
\hline $\begin{array}{l}\text { T-Förvärvsarbete i hushåll; } \\
\text { hushållens produktion av diverse } \\
\text { varor och tjänster för eget bruk }\end{array}$ & 2 & 2 & 0 & 2 & 2 & 0 & 0 & 0 & 0 \\
\hline $\begin{array}{l}\text { U-Verksamhet vid internationella } \\
\text { organisationer, utländska } \\
\text { ambassader o.d. }\end{array}$ & 0 & 0 & 0 & 0 & 0 & 0 & 0 & 0 & 0 \\
\hline Okänd näringsgren & 34 & 11 & 23 & 31 & 10 & 21 & 3 & 1 & 2 \\
\hline
\end{tabular}

${ }^{1}$ Näringsgrensindelningen är på bokstavsnivå utifrån SNI 2007. 
Tabell 5aa. Förändring av antal danska arbetspendlare 2009 jämfört med 2008 efter näringsgren och kön

\begin{tabular}{|c|c|c|c|c|c|c|c|c|c|}
\hline \multirow[t]{3}{*}{ Procentuell förändring av danska arbetspendlare } & \multirow[b]{3}{*}{ Totalt } & \multirow[b]{3}{*}{ Män } & \multirow[b]{3}{*}{ Kv } & \multicolumn{6}{|c|}{ Därav till } \\
\hline & & & & \multicolumn{2}{|c|}{ Norge } & \multicolumn{4}{|c|}{ Sverige } \\
\hline & & & & Totalt & Män & Kv & Totalt & Män & Kv \\
\hline Alla näringsgrenar & $-2,9$ & $-5,5$ & 1,9 & 1,0 & $-1,4$ & 4,9 & $-12,2$ & $-14,5$ & $-7,1$ \\
\hline A-Jordbruk, jakt, fiske & $-3,3$ & 24,2 & $-35,7$ & $-9,3$ & 6,7 & $-29,2$ & 42,9 & 200,0 & $-75,0$ \\
\hline B-Utvinning av mineral & $-21,1$ & $-20,6$ & $-35,7$ & $-20,7$ & $-20,2$ & $-35,7$ & $-100,0$ & $-100,0$ & \\
\hline C-Tillverkning & $-11,8$ & $-11,4$ & $-14,0$ & $-11,2$ & $-10,1$ & $-17,6$ & $-13,0$ & $-14,3$ & $-6,3$ \\
\hline D-Försörjning av el, gas, värme och kyla & 400,0 & 200,0 & 100,0 & 100,0 & & 100,0 & 200,0 & 200,0 & \\
\hline E-Vattenförsörjning; avloppsrening, avfallshantering och sanering & 175,0 & 166,7 & 100,0 & 328,6 & 314,3 & 100,0 & $-40,0$ & $-40,0$ & \\
\hline F-Byggverksamhet & 3,8 & 3,6 & 8,3 & 7,0 & 7,2 & 0,0 & $-42,1$ & $-52,9$ & 50,0 \\
\hline G-Handel; reparation av motorfordon och motorcyklar & 16,0 & 11,6 & 20,5 & 29,1 & 31,5 & 27,8 & $-6,7$ & $-4,3$ & $-14,6$ \\
\hline H-Transport och magasinering & $-0,3$ & 1,2 & $-5,6$ & 4,2 & 3,9 & 5,1 & $-4,9$ & $-1,5$ & $-18,8$ \\
\hline I-Hotell- och restaurangverksamhet & 11,7 & 20,7 & 6,5 & 12,2 & 27,4 & 4,7 & 5,6 & $-14,3$ & 75,0 \\
\hline J-Informations- och kommunikationsverksamhet & $-14,2$ & $-12,5$ & $-16,9$ & $-8,9$ & 7,1 & $-27,0$ & $-19,7$ & $-27,8$ & 0,0 \\
\hline K-Finans- och försäkringsverksamhet & 13,3 & 5,4 & 26,1 & 4,2 & $-18,2$ & 23,1 & 19,4 & 15,4 & 30,0 \\
\hline L-Fastighetsverksamhet & $-7,4$ & $-17,6$ & 10,0 & $-8,3$ & $-21,4$ & 10,0 & 0,0 & 0,0 & \\
\hline M-Verksamhet inom juridik, ekonomi, vetenskap och teknik & $-14,2$ & $-20,6$ & $-4,0$ & $-10,0$ & $-25,9$ & 17,7 & $-17,5$ & $-16,2$ & $-19,5$ \\
\hline N-Uthyrning, fastightsservice, resetjänster och andra stödtjänster & $-1,6$ & 5,6 & $-15,7$ & 1,8 & 9,7 & $-12,9$ & $-28,6$ & $-22,6$ & $-45,5$ \\
\hline O-Offentlig förvaltning och försvar; obligatorisk socialförsäkring & $-11,9$ & $-16,1$ & $-8,7$ & $-17,3$ & $-22,8$ & $-12,7$ & 46,2 & 70,0 & 31,3 \\
\hline P-Utbildning & $-4,6$ & $-8,0$ & $-1,1$ & 0,0 & 19,2 & $-12,2$ & $-7,0$ & $-17,6$ & 7,4 \\
\hline Q-Vård och omsorg; sociala tjänster & $-5,5$ & $-22,7$ & 11,2 & 4,8 & $-9,3$ & 13,2 & $-23,1$ & $-34,7$ & 3,9 \\
\hline R-Kultur, nöje och fritid & 0,6 & $-7,7$ & 8,6 & 25,0 & 12,2 & 37,2 & $-26,7$ & $-29,7$ & $-23,7$ \\
\hline S-Annan serviceverksamhet & 18,5 & 14,3 & 21,2 & 36,8 & 54,5 & 29,6 & $-25,0$ & $-30,0$ & $-16,7$ \\
\hline T-Förvärvsarbete i hushåll; hushållens produktion av diverse varor och tjänster för eget bruk & 100,0 & 100,0 & .. & 100,0 & 100,0 & .. & &. & \\
\hline U-Verksamhet vid internationella organisationer, utländska ambassader o.d. & .. & &.. & & .. &.. &.. &.. & \\
\hline Okänd näringsgren & $-8,1$ & $-8,3$ & $-8,0$ & $-8,8$ & 11,1 & $-16,0$ & 0,0 & $-66,7$ & 100,0 \\
\hline
\end{tabular}

${ }^{1}$ Näringsgrensindelningen är på bokstavsnivå utifrån SNI 2007. 
Tabell 5b. Antal norska arbetspendlare efter näringsgren och kön 2009

Totalt antal norska arbetspendlare

Därav till

\begin{tabular}{|c|c|c|c|c|c|c|c|c|c|}
\hline \multirow[b]{2}{*}{ Näringsgren1 } & \multirow[b]{2}{*}{ Totalt } & \multirow[b]{2}{*}{ Män } & \multirow[b]{2}{*}{ Kv } & \multicolumn{3}{|c|}{ Danmark } & \multicolumn{3}{|c|}{ Sverige } \\
\hline & & & & Totalt & Män & Kv & Totalt & Män & Kv \\
\hline Alla näringsgrenar & 1158 & 755 & 403 & 325 & 232 & 93 & 833 & 523 & 310 \\
\hline A-Jordbruk, jakt, fiske & 10 & 6 & 4 & 4 & 2 & 2 & 6 & 4 & 2 \\
\hline B-Utvinning av mineral & 8 & 6 & 2 & 3 & 3 & 0 & 5 & 3 & 2 \\
\hline C-Tillverkning & 73 & 58 & 15 & 19 & 15 & 4 & 54 & 43 & 11 \\
\hline D-Försörjning av el, gas, värme och kyla & 5 & 4 & 1 & 4 & 4 & 0 & 1 & 0 & 1 \\
\hline E-Vattenförsörining; avloppsrening, avfallshantering och sanering & 0 & 0 & 0 & 0 & 0 & 0 & 0 & 0 & 0 \\
\hline F-Byggverksamhet & 32 & 28 & 4 & 10 & 9 & 1 & 22 & 19 & 3 \\
\hline G-Handel; reparation av motorfordon och motorcyklar & 297 & 149 & 148 & 29 & 22 & 7 & 268 & 127 & 141 \\
\hline $\mathrm{H}$-Transport och magasinering & 167 & 152 & 15 & 84 & 73 & 11 & 83 & 79 & 4 \\
\hline I-Hotell- och restaurangverksamhet & 52 & 27 & 25 & 8 & 3 & 5 & 44 & 24 & 20 \\
\hline J-Informations- och kommunikationsverksamhet & 35 & 30 & 5 & 7 & 6 & 1 & 28 & 24 & 4 \\
\hline K-Finans- och försäkringsverksamhet & 24 & 17 & 7 & 12 & 9 & 3 & 12 & 8 & 4 \\
\hline L-Fastighetsverksamhet & 17 & 13 & 4 & 1 & 0 & 1 & 16 & 13 & 3 \\
\hline M-Verksamhet inom juridik, ekonomi, vetenskap och teknik & 70 & 45 & 25 & 18 & 12 & 6 & 52 & 33 & 19 \\
\hline N-Uthyrning, fastighetsservice, resetjänster och andra stödtjänster & 58 & 39 & 19 & 23 & 17 & 6 & 35 & 22 & 13 \\
\hline O-Offentlig förvaltning och försvar; obligatorisk socialförsäkring & 48 & 29 & 19 & 18 & 15 & 3 & 30 & 14 & 16 \\
\hline P-Utbildning & 93 & 54 & 39 & 22 & 9 & 13 & 71 & 45 & 26 \\
\hline Q-Vård och omsorg; sociala tjänster & 109 & 57 & 52 & 50 & 24 & 26 & 59 & 33 & 26 \\
\hline R-Kultur, nöje och fritid & 51 & 34 & 17 & 9 & 7 & 2 & 42 & 27 & 15 \\
\hline S-Annan serviceverksamhet & 7 & 5 & 2 & 3 & 1 & 2 & 4 & 4 & 0 \\
\hline T-Förvärvsarbete i hushåll; hushållens produktion av diverse varor och tjänster för eget bruk & 0 & 0 & 0 & 0 & 0 & 0 & 0 & 0 & 0 \\
\hline U-Verksamhet vid internationella organisationer, utländska ambassader o.d. & 1 & 1 & 0 & 1 & 1 & 0 & 0 & 0 & 0 \\
\hline Okänd näringsgren & 1 & 1 & 0 & 0 & 0 & 0 & 1 & 1 & 0 \\
\hline
\end{tabular}

${ }^{1}$ Näringsgrensindelningen är på bokstavsnivå utifrån SNI 2007. 
Tabell 5bb. Förändring av antal norska arbetspendlare 2009 jämfört med 2008 efter näringsgren och kön

\begin{tabular}{|c|c|c|c|c|c|c|c|c|c|}
\hline \multirow{3}{*}{ Procentuell förändring av norska arbetspendlare } & \multirow[b]{3}{*}{ Totalt } & \multirow[b]{3}{*}{ Män } & \multirow[b]{3}{*}{ Kv } & \multicolumn{6}{|c|}{ Därav till } \\
\hline & & & & \multicolumn{2}{|c|}{ Danmark } & \multicolumn{4}{|c|}{ Sverige } \\
\hline & & & & Totalt & Män & Kv & Totalt & Män & Kv \\
\hline Alla näringsgrenar & $-20,5$ & $-15,5$ & $-28,5$ & $-17,5$ & 1,8 & $-44,0$ & $-21,6$ & $-21,4$ & $-22,1$ \\
\hline A-Jordbruk, jakt, fiske & $-16,7$ & $-33,3$ & 33,3 & $-20,0$ & $-33,3$ & 0,0 & $-14,3$ & $-33,3$ & 100,0 \\
\hline B-Utvinning av mineral & 14,3 & $-14,3$ & 100,0 & 0,0 & 0,0 & .. & 25,0 & $-25,0$ & .. \\
\hline C-Tillverkning & $-37,1$ & $-38,9$ & $-28,6$ & $-38,7$ & $-31,8$ & $-55, \ddot{6}$ & $-36,5$ & $-41,1$ & $-8,3$ \\
\hline D-Försörining av el, gas, värme och kyla & $-50,0$ & $-50,0$ & $-50,0$ & 33,3 & 33,3 & .. & $-85,7$ & $-100,0$ & $-50,0$ \\
\hline E-Vattenförsörjning; avloppsrening, avfallshantering och sanering & & .. & .. & .. & & .. & & & . \\
\hline F-Byggverksamhet & $-41,8$ & $-44,0$ & $-20,0$ & $-47,4$ & $-50,0$ & 0,0 & $-38,9$ & $-40,6$ & $-25,0$ \\
\hline G-Handel; reparation av motorfordon och motorcyklar & $-17,7$ & $-7,5$ & $-26,0$ & $-14,7$ & 83,3 & $-68,2$ & $-18,0$ & $-14,8$ & $-20,8$ \\
\hline $\mathrm{H}$-Transport och magasinering & $-4,6$ & $-3,2$ & $-16,7$ & 13,5 & 10,6 & 37,5 & $-17,8$ & $-13,2$ & $-60,0$ \\
\hline 1-Hotell- och restaurangverksamhet & $-36,6$ & $-15,6$ & $-50,0$ & $-38,5$ & $-50,0$ & $-28,6$ & $-36,2$ & $-7,7$ & $-53,5$ \\
\hline J-Informations- och kommunikationsverksamhet & $-22,2$ & $-14,3$ & $-50,0$ & $-56,3$ & $-50,0$ & $-75,0$ & $-3,4$ & 4,3 & $-33,3$ \\
\hline K-Finans- och försäkringsverksamhet & $-20,0$ & $-10,5$ & $-36,4$ & 0,0 & 50,0 & $-50,0$ & $-33,3$ & $-38,5$ & $-20,0$ \\
\hline L-Fastighetsverksamhet & 6,3 & 30,0 & $-33,3$ & $-66,7$ & .. & $-66,7$ & 23,1 & 30,0 & 0,0 \\
\hline M-Verksamhet inom juridik, ekonomi, vetenskap och teknik & $-29,3$ & $-33,8$ & $-19,4$ & $-28,0$ & $-25,0$ & $-33,3$ & $-29,7$ & $-36,5$ & $-13,6$ \\
\hline N-Uthyrning, fastighetsservice, resetjänster och andra stödtjänster & $-15,9$ & $-22,0$ & 0,0 & 0,0 & 0,0 & 0,0 & $-23,9$ & $-33,3$ & 0,0 \\
\hline O-Offentlig förvaltning och försvar; obligatorisk socialförsäkring & 9,1 & 70,6 & $-29,6$ & 200,0 & 650,0 & $-25,0$ & $-21,1$ & $-6,7$ & $-30,4$ \\
\hline P-Utbildning & 5,7 & 14,9 & $-4,9$ & $-8,3$ & $-18,2$ & 0,0 & 10,9 & 25,0 & $-7,1$ \\
\hline Q-Vărd och omsorg; sociala tjänster & $-34,7$ & $-17,4$ & $-46,9$ & $-45,1$ & $-4,0$ & $-60,6$ & $-22,4$ & $-25,0$ & $-18,8$ \\
\hline R-Kultur, nöje och fritid & $-12,1$ & $-20,9$ & 13,3 & 28,6 & 133,3 & $-50,0$ & $-17,6$ & $-32,5$ & 36,4 \\
\hline S-Annan serviceverksamhet & $-61,1$ & $-54,5$ & $-71,4$ & $-40,0$ & $-66,7$ & 0,0 & $-69,2$ & $-50,0$ & $-100,0$ \\
\hline T-Förvärvsarbete i hushåll; hushållens produktion av diverse varor och tjänster för eget bruk & .. & .. & .. & .. & .. & .. & .. & & .. \\
\hline U-Verksamhet vid internationella organisationer, utländska ambassader o.d. & 100,0 & 100,0 & .. & 100,0 & 100,0 &.. & & & .. \\
\hline Okänd näringsgren & $-80,0$ & $-80,0$ & .. & .. & .. &.. & $-80,0$ & $-80,0$ & .. \\
\hline
\end{tabular}

${ }^{1}$ Näringsgrensindelningen är på bokstavsnivå utifrån SNI 2007. 
Tabell 5c. Antal svenska arbetspendlare efter näringsgren SNI och kön 2009

\begin{tabular}{|c|c|c|c|c|c|c|c|c|c|}
\hline \multirow[t]{3}{*}{ Totalt antal svenska arbetspendlare } & \multirow[b]{3}{*}{ Totalt } & \multirow[b]{3}{*}{ Män } & \multirow[b]{3}{*}{$\mathrm{Kv}$} & \multicolumn{6}{|c|}{ Därav till } \\
\hline & & & & \multicolumn{3}{|c|}{ Danmark } & \multicolumn{3}{|c|}{ Norge } \\
\hline & & & & Totalt & Män & Kv & Totalt & Män & Kv \\
\hline Alla näringsgrenar & 48330 & 31079 & 17251 & 20189 & 11949 & 8240 & 28141 & 19130 & 9011 \\
\hline A-Jordbruk, jakt, fiske & 276 & 212 & 64 & 21 & 14 & 7 & 255 & 198 & 57 \\
\hline B-Utvinning av mineral & 343 & 309 & 34 & 39 & 28 & 11 & 304 & 281 & 23 \\
\hline C-Tillverkning & 4472 & 3605 & 867 & 1616 & 1171 & 445 & 2856 & 2434 & 422 \\
\hline D-Försörjning av el, gas, värme och kyla & 59 & 44 & 15 & 43 & 35 & 8 & 16 & 9 & 7 \\
\hline E-Vattenförsörjning; avloppsrening, avfallshantering och sanering & 97 & 91 & 6 & 42 & 39 & 3 & 55 & 52 & 3 \\
\hline F-Byggverksamhet & 5360 & 5264 & 96 & 590 & 568 & 22 & 4770 & 4696 & 74 \\
\hline G-Handel; reparation av motorfordon och motorcyklar & 6339 & 3433 & 2906 & 3452 & 1861 & 1591 & 2887 & 1572 & 1315 \\
\hline $\mathrm{H}$-Transport och magasinering & 5313 & 4069 & 1244 & 3091 & 2163 & 928 & 2222 & 1906 & 316 \\
\hline I-Hotell- och restaurangverksamhet & 4315 & 1968 & 2347 & 1448 & 822 & 626 & 2867 & 1146 & 1721 \\
\hline J-Informations- och kommunikationsverksamhet & 1749 & 1346 & 403 & 1308 & 1027 & 281 & 441 & 319 & 122 \\
\hline K-Finans- och försäkringsverksamhet & 1026 & 632 & 394 & 924 & 561 & 363 & 102 & 71 & 31 \\
\hline L-Fastighetsverksamhet & 305 & 206 & 99 & 160 & 98 & 62 & 145 & 108 & 37 \\
\hline M-Verksamhet inom juridik, ekonomi, vetenskap och teknik & 2040 & 1318 & 722 & 1330 & 768 & 562 & 710 & 550 & 160 \\
\hline N-Uthyrning, fastighetsservice, resetjänster och andra stödtjänster & 7977 & 5082 & 2895 & 1432 & 876 & 556 & 6545 & 4206 & 2339 \\
\hline O-Offentlig förvaltning och försvar; obligatorisk socialförsäkring & 1242 & 662 & 580 & 608 & 377 & 231 & 634 & 285 & 349 \\
\hline P-Utbildning & 1006 & 556 & 450 & 726 & 400 & 326 & 280 & 156 & 124 \\
\hline Q-Vård och omsorg; sociala tjänster & 4880 & 1451 & 3429 & 2642 & 732 & 1910 & 2238 & 719 & 1519 \\
\hline R-Kultur, nöje och fritid & 952 & 564 & 388 & 394 & 251 & 143 & 558 & 313 & 245 \\
\hline S-Annan serviceverksamhet & 495 & 210 & 285 & 286 & 133 & 153 & 209 & 77 & 132 \\
\hline T-Förvärvsarbete i hushåll; hushållens produktion av diverse varor och tjänster för eget bruk & 11 & 8 & 3 & 6 & 4 & 2 & 5 & 4 & 1 \\
\hline U-Verksamhet vid internationella organisationer, utländska ambassader o.d. & 32 & 21 & 11 & 31 & 21 & 10 & 1 & 0 & 1 \\
\hline Okänd näringsgren & 41 & 28 & 13 & 0 & 0 & 0 & 41 & 28 & 13 \\
\hline
\end{tabular}

${ }^{1}$ Näringsgrensindelningen är på bokstavsnivå utifrån SNI 2007. 
Tabell 5cc. Förändring av antal svenska arbetspendlare 2009 jämört med 2008 efter näringsgren och kön

\begin{tabular}{|c|c|c|c|c|c|c|c|c|c|}
\hline \multicolumn{4}{|l|}{ Procentuell förändring av svenska arbetspendlare } & \multicolumn{6}{|c|}{ Därav till } \\
\hline \multirow[b]{2}{*}{ Näringsgren1 } & \multirow[b]{2}{*}{ Totalt } & \multirow[b]{2}{*}{ Män } & \multirow[b]{2}{*}{ Kv } & \multicolumn{3}{|c|}{ Danmark } & \multicolumn{3}{|c|}{ Norge } \\
\hline & & & & Totalt & Män & Kv & Totalt & Män & $\mathrm{Kv}$ \\
\hline Alla näringsgrenar & 2,8 & 2,0 & 4,1 & $-3,0$ & $-3,5$ & $-2,3$ & 7,3 & 5,8 & 10,8 \\
\hline A-Jordbruk, jakt, fiske & 13,6 & 9,3 & 30,6 & 0,0 & 27,3 & $-30,0$ & 14,9 & 8,2 & 46,2 \\
\hline B-Utvinning av mineral & $-4,5$ & $-5,2$ & 3,0 & 18,2 & 16,7 & 22,2 & $-6,7$ & $-7,0$ & $-4,2$ \\
\hline C-Tillverkning & $-1,7$ & $-0,4$ & $-6,7$ & $-9,4$ & $-10,4$ & $-6,7$ & 3,3 & 5,2 & $-6,6$ \\
\hline D-Försörjning av el, gas, värme och kyla & $-11,9$ & $-8,3$ & $-21,1$ & $-15,7$ & $-5,4$ & $-42,9$ & 0,0 & $-18,2$ & 40,0 \\
\hline E-Vattenförsörjning; avloppsrening, avfallshantering och sanering & 6,6 & 12,3 & $-40,0$ & $-12,5$ & $-11,4$ & $-25,0$ & 27,9 & 40,5 & $-50,0$ \\
\hline F-Byggverksamhet & $-0,4$ & $-0,6$ & 6,7 & $-25,1$ & $-25,3$ & $-21,4$ & 3,8 & 3,6 & 19,4 \\
\hline G-Handel; reparation av motorfordon och motorcyklar & 2,4 & 3,6 & 1,1 & $-8,8$ & $-7,2$ & $-10,6$ & 20,1 & 20,2 & 20,1 \\
\hline H-Transport och magasinering & 6,9 & 8,5 & 1,8 & 4,3 & 5,2 & 2,3 & 10,6 & 12,5 & 0,3 \\
\hline 1-Hotell- och restaurangverksamhet & 8,9 & 7,7 & 9,8 & $-7,1$ & $-5,2$ & $-9,4$ & 19,2 & 19,4 & 19,0 \\
\hline J-Informations- och kommunikationsverksamhet & $-2,9$ & $-3,5$ & $-1,0$ & $-6,1$ & $-6,8$ & $-3,4$ & 7,8 & 8,9 & 5,2 \\
\hline K-Finans- och försäkringsverksamhet & $-2,2$ & $-2,9$ & $-1,0$ & $-1,5$ & $-1,1$ & $-2,2$ & $-8,1$ & $-15,5$ & 14,8 \\
\hline L-Fastighetsverksamhet & 15,1 & 7,3 & 35,6 & 10,3 & $-3,9$ & 44,2 & 20,8 & 20,0 & 23,3 \\
\hline M-Verksamhet inom juridik, ekonomi, vetenskap och teknik & $-2,2$ & $-2,9$ & $-1,0$ & $-7,4$ & $-10,2$ & $-3,4$ & 9,4 & 9,6 & 8,8 \\
\hline $\mathrm{N}$-Uthyrning, fastighetsservice, resetjänster och andra stödtjänster & $-5,9$ & $-5,1$ & $-7,2$ & $-5,1$ & 0,5 & $-12,7$ & $-6,0$ & $-6,2$ & $-5,8$ \\
\hline O-Offentlig förvaltning och försvar; obligatorisk socialförsäkring & 11,2 & 12,8 & 9,4 & 7,2 & 8,6 & 5,0 & 15,3 & 18,8 & 12,6 \\
\hline P-Utbildning & 13,4 & 14,2 & 12,5 & 15,1 & 18,3 & 11,3 & 9,4 & 4,7 & 15,9 \\
\hline Q-Vård och omsorg; sociala tjänster & 20,0 & 22,6 & 19,0 & 9,2 & 10,6 & 8,7 & 36,0 & 37,7 & 35,1 \\
\hline R-Kultur, nöje och fritid & 7,7 & 7,6 & 7,8 & $-11,5$ & $-9,4$ & $-14,9$ & 27,1 & 26,7 & 27,6 \\
\hline S-Annan serviceverksamhet & 18,1 & 16,7 & 19,2 & 8,3 & 9,0 & 7,7 & 34,8 & 32,8 & 36,1 \\
\hline T-Förvärvsarbete i hushåll; hushållens produktion av diverse varor och tjänster för eget bruk & $-21,4$ & $-11,1$ & $-40,0$ & $-14,3$ & 0,0 & $-33,3$ & $-28,6$ & $-20,0$ & $-50,0$ \\
\hline U-Verksamhet vid internationella organisationer, utländska ambassader o.d. & 28,0 & 23,5 & 37,5 & 29,2 & 23,5 & 42,9 & 0,0 & .. & 0,0 \\
\hline Okänd näringsgren & $-67,2$ & $-60,0$ & $-76,4$ & .. &.. & .. & $-67,2$ & $-60,0$ & $-76,4$ \\
\hline
\end{tabular}

${ }^{1}$ Näringsgrensindelningen är på bokstavsnivå utifrån SNI 2007. 
Nordiska ministerrådet

Ved Stranden 18

DK-1061 København K

www.norden.org

\section{Nordisk pendlingskarta 2012 \\ Baserat på statistik från 2009}

Statistiken avser år 2009 och visar att närmare 70.000 nordbor gränspendlade under 2009. Den samlade lönesumman för gränspendlare uppgick till 25 miljarder SEK, varav 22 miljarder av summan tjänades av svenskar i Danmark och Norge.

Sedan 2001 har antalet gränspendlare i Norden ökat med mer än 100 procent, men 2009 ökade inte längre antalet i lika hög takt som tidigare*. Den kraftiga expansionen av svensk gränspendling till Danmark och Norge saktade in under 2009. Ökningen var knappt 3 procent, att jämföras med åren 2006-2008 då den var nära 20 procent, eller cirka 7000 personer per år. Den danska gränspendlingen till Norge och Sverige låg kvar på samma nivå som under 2008, medan den norska pendlingen till Danmark och Sverige minskade med 20 procent. Pendlingen är starkt beroende av ländernas arbetsmarknad och av goda kommunikationer.

*De tidigare sammanställningarna av pendlingsförhållandena i Norden baserades på situationen åren 2001, 2004, 2005, 2006 respektive 2008. Finland ingår i de fyra första årgångarna av rapporten.

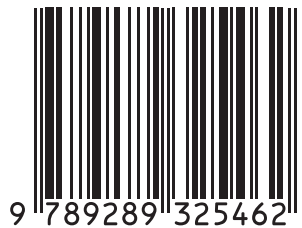

